\title{
Recent advances in sustainable drying of agricultural produce: A review
}

\author{
Rasaq. O. Lamidi, L. Jiang*, Pankaj B. Pathare, Y. D. Wang, A.P. Roskilly \\ Sir Joseph Swan Centre for Energy Research, Newcastle University, Newcastle NE1 7RU, UK
}

\begin{abstract}
Quests for sustainability, food security and need to decouple food prices from fluctuating prices of finite fossil fuels are the drivers to sustainable processing and storage of agricultural products. Farming predominantly takes place in rural areas where conventional energy technologies may either be expensive or sometimes technically infeasible to be obtained. This necessitates deployments of renewable energy technologies to remote areas for sustainable power generation, cooling and drying of agricultural product. Renewable systems e.g. solar dryers, solar hybrid dryers, combined power and drying system take leading roles in sustainable drying of farm produce. A number of research studies have been carried out in the past one decade, which mainly concentrate on modelling, simulation and experiment of different sustainable drying techniques. Therefore, this paper mainly aims to present a state of the art review on the contributions of combined power and drying, application of phase change materials and hybrid drying systems with regard to agricultural products. Based on this comprehensive summarization, it is indicated that deployment of biomass powered combined heat and power systems might be a good solution to post-harvest wastes since both electricity and heat for drying of agricultural products can be simultaneously obtained.
\end{abstract}

Keywords: Renewable energy; Rural area; Agricultural product; Sustainable drying

* Corresponding author. Tel. $+44-07592206270$

Email: Long.jiang@newcastle.ac.uk(L.Jiang) 
Contents:

1. Introduction

2. Physics of renewable energy drying

3. Hybrid drying

4. Waste/Recovered heat for food drying

5. Phase change materials used for food drying

6. Effect of different drying methods on quality of agriculture products

7. Mathematical/computational modelling approaches used for sustainable drying

8. Exergy analysis

9. Economic evaluation of the drying units

10. Life cycle assessment study on sustainable drying of agricultural products

11. Conclusions

Acknowledgements

References 


\section{Nomenclature}

General signs

A

C

E

F

I

LHV

P

Q

$\mathrm{T}$

W

X

Y

\section{Acronyms}

$\mathrm{AD}$

CFD

CFA

CHP

COP

d.b.

GHG

HP

LCA

LPG

MOF

NPV

NS

ORC

PCM
Area $\left(m^{2}\right)$

Specific heat $\left(\mathrm{kJ} \cdot \mathrm{kg}^{-1} \cdot \mathrm{K}^{-1}\right)$

Energy (kJ)

Flow rate $\left(\mathrm{kg} \cdot \mathrm{s}^{-1}\right)$

Solar irradiance $\left(\mathrm{W} \cdot \mathrm{m}^{-2}\right)$

Low heat value $\left(\mathrm{kJ} \cdot \mathrm{kg}^{-1}\right)$

Pressure $(\mathrm{Pa})$

Energy $\left(\mathrm{kJ} \cdot \mathrm{h}^{-1}\right)$

Temperature $\left({ }^{\circ} \mathrm{C}\right)$

Feed rate $\left(\mathrm{kg} \cdot \mathrm{h}^{-1}\right)$

Moisture content $\left(\mathrm{kg} \mathrm{H}_{2} \mathrm{O} \cdot \mathrm{kg}^{-1}\right.$ dry material)

Absolute air humidity $\left(\mathrm{kg} \mathrm{H}_{2} \mathrm{O} \cdot \mathrm{kg}^{-1}\right.$ dry air)

Anaerobic digestion

Computational fluid dynamic

Central African francs

Combine heat and power

Coefficient of performance

Dry base

Greenhouse gas

Heat pump

Life cycle assessment

Liquid petroleum gas

Metal organic frameworks

Net present value

Navier-Stokes

Organic Rankine cycle

Phase change material 
PV

$\mathrm{PV} / \mathrm{T}$

RANS

RET

TES

WHR

w.b.

\section{Subscripts}

a

c

d

ex

da

f

fw

geo

$\mathrm{h}$

i

1

o

pc

sl

th

W

V

Greek Signs

$\Delta H$

$\mu$

$\dot{m}$
Photovoltaic

Photovoltaic and thermal

Reynolds-averaged Navier-Stokes

Renewable energy technology

Thermal enegy storage

Waste heat recovery

Wet base

Ambient

Collector

Drying

Heat exchanger

Drying air

Final

Fuelwood

Geothermal

Heat

Initial

Latent

Outlet

Phase changing

Sensible and latent heat

Thermal

Water

Vapourisation

Latent heat $\left(\mathrm{kJ} \cdot \mathrm{kg}^{-1}\right)$

Efficiency (\%)

Flowrate $\left(\mathrm{kg} \cdot \mathrm{h}^{-1}\right)$ 


\section{Introduction}

Drying is the removal of moisture e.g. reducing water activity from a product, which could slow down the pace of deterioration and maintain the quality [1]. If agricultural product is dried to remove the maximum moisture with active nutrients remained, it can be safely preserved for many days [2]. It is also a process in which free water in the food is significantly reduced, thus leading to concentration of dry matter without damaging the tissue, wholesomeness and physical appearance of the food [3]. Heat and mass transfer within the material are involved in this drying process [4]. Sun drying is generally considered as a traditional method which is employed in most developing countries of the world [5]. Although this technology is cheap and freely available, the product is often subjected to uncontrolled long time drying period, exposure to contamination and low quality of dried products [6]. Therefore, outbreak of food born disease is an occasional challenge of smallholders' farmers due to the growth of toxic fungi in sundried crops [7]. Comparably, modern drying systems are carried out under controlled conditions which could supply products with better quality. However, these systems are often not only expensive but also highly energy intensive [8]. Meanwhile, present global food demand brings about increasing use of fossil fuels in all stages of food chain. Statistics indicate that by 2030 global demands for energy and food are expected to be increased by $40 \%$ and $50 \%[9,10]$. At the moment, about 95 EJ of energy is being consumed annually in food sector. High and low GDP countries account for 50 EJ and 45 EJ with regard to their different compositions of energy usage as illustrated in Fig. 1 [11]. Considering environmental concerns and finite nature of fossil fuels, it is necessary to further reduce energy consumption in food sector, which is able to decouple food prices from the unstable and increasing prices of fossil fuels [12]. Thus, it is desirable to use renewable energy for the drying of agriculture products.

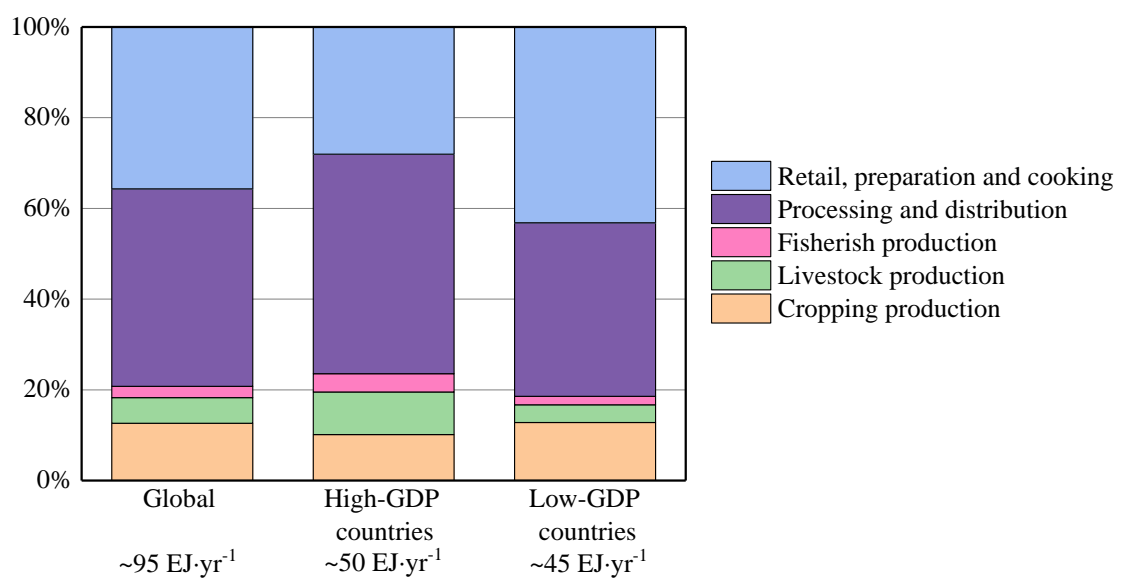

Fig. 1. Global energy usage in food sector [11]. 
Deployment of renewable energy technology (RET) in food drying is regarded as a good approach since renewable energy is continuously replenishing energy source [13]. It could be directly derived from sun e.g. thermal, photo-chemical, photo-electric effect, indirectly from sun e.g. wind, hydropower, photosynthetic energy in biomass, and other natural environmental movements or mechanisms e.g. geothermal and tidal energy $[14,15]$. Hence, energy from fossil fuel and its derivatives are not adopted. These energy sources are able to be transferred into various energy forms in terms of electricity, heating and transport fuels by RET [16]. Also worth noting that more than 3000 times the current global energy demand can be produced from renewable energy sources [17]. Therefore, there is need to consciously increase the share of these renewable energies in the global energy mix. At the moment, most rural areas particularly in the global south lack access to modern energy on which adoption and operation of sophisticated dryers depend. Besides, most of these rural areas, whose occupants are predominantly subsistence farmers, are either too far from the main cities or topographically challenging to be connected to the centralised national grid. Thus these reasons result in drivers to the use of renewable energy in the post-harvest drying of agricultural products [18]. A sustainable drying refers to the drying of agricultural product with little or no fossil fuel input. Alternative fuels or energy sources are used to realize agricultural product drying, which could reduce impact of food drying on the environment [19]. In spite of some barriers, RET has been predicted to be a suitable strategy for food drying which brings some benefits such as low cost, high efficiency, increasing employment opportunities, etc. [20]. Two main research approaches to sustainable food drying are presented as follows [21]:

[1] Improving the efficiency of the dryer, which may be achieved through insulation, heat recovery, recirculation and altering operating constraints of the systems.

[2] Improving or substituting the system's energy supply by using combined heat and power (CHP), biomass derived fuels and other renewable energy sources.

Based on the above approaches, drying can be sustainably achieved by means of solar system, biomass units, geothermal system, waste/recovered heat or combination of two or more systems i.e. hybrid drying [22]. It is recognized that drying technologies have been extensively investigated while many of these studies have been reviewed particularly in terms of drying heat sources, configurations and optimisations especially from both experimental and modelling perspectives. However, to the best of authors' knowledge, less research studies about sustainable drying of agricultural product have been well summarized, especially in context of smallholder's farmers. The strategy to sustainable drying is 
presented in Fig. 2, which also reflects the research scope of this paper in terms of two main approaches. It is worth noting that the main lines of this review will focus on hybrid drying systems and waste heat recovery for food drying. Hybrid drying systems concentrate on solar combined with other technologies e.g. biomass drying, heat pump, etc. and solar integrated with heat storage systems as indicated in dashed area, which aim to overcome the deficiencies of single renewable drying system [23].

There exist previous review works on solar dryers: modelling techniques [24]; solar drying technologies [25]; solar greenhouse drying [26]; economic and environmental aspect of solar drying [27] and solar system with latent heat storage $[28,29]$, separately. However, most of these studies focus on solar drying technology while review works on solar hybrid systems, waste heat recovery for crop drying and economic analysis of these integrated systems are scanty. Hence, it is aimed to be a "one stop shop" based on the recent studies regarding aforementioned aspects of crop drying, and some representative case studies are presented. The overarching framework of this paper is elaborated as follows: The physics of drying is presented in section 2. Three drying fields are introduced in sections 3, 4 and 5, in which section 3 and 4 are drying technologies while section 5 is heat storage part. Then effects on product quality by using different drying methods are compared in section 6. Modelling approaches used for sustainable drying are discussed in section 7 followed by exergy analysis in section 8 and economic evaluation in section 9. The environmental impact of sustainable drying is discussed in section 10. Eventually the conclusions are presented in section 11 .

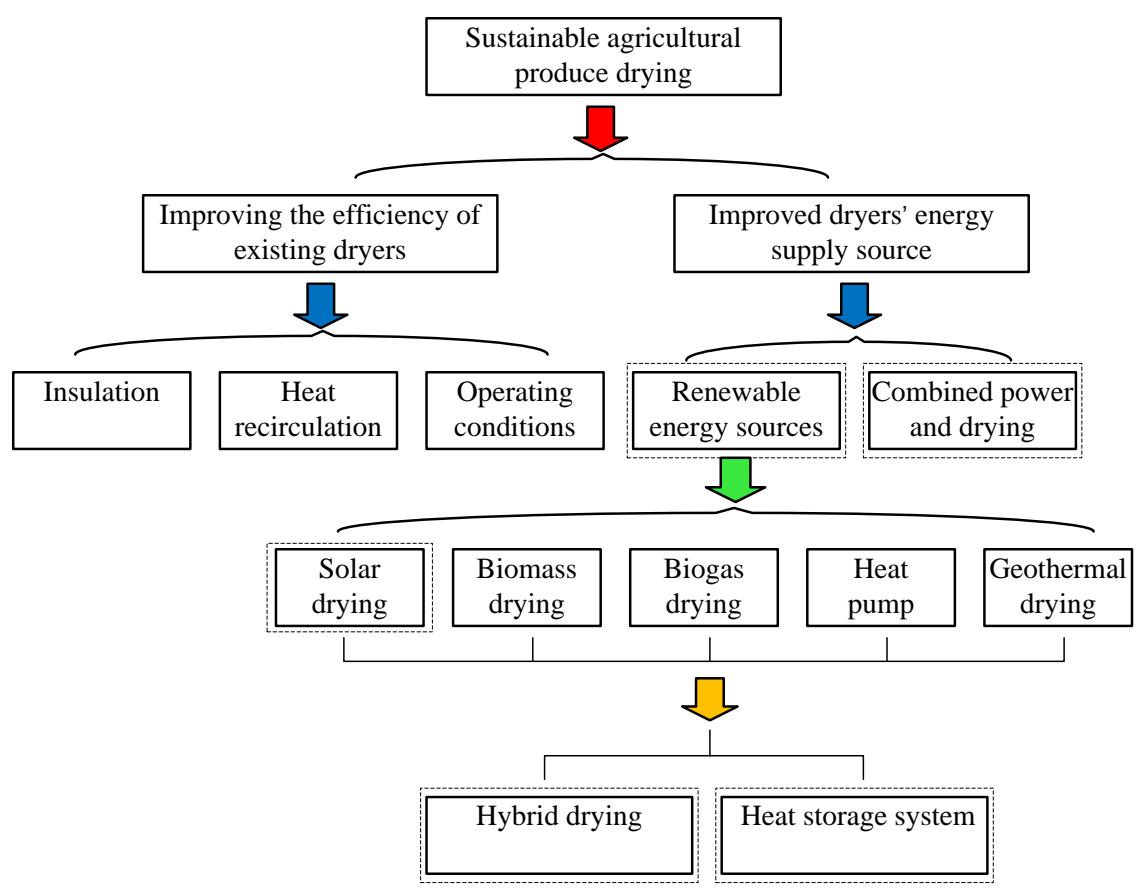


Fig. 2. Strategies to sustainable food drying [authors].

\section{Physics of renewable energy drying}

The primary aim of food drying is to lower water activity of the food to a level where microbial growth and reaction rate is slowed (typically less than 0.6). Two guiding principles of drying are as follows [30]: (1) Heat transfer to supply the required latent heat of vaporization; (2) Movement of water or water vapour through food material and its subsequent separation from the food.

Drying is mostly achieved through air drying, vacuum drying or freeze drying [31]. In either of the above method, drying is achieved by taking advantage of different states of water and vapour pressure. The main interest of this study lies in air drying due to the fact that it is the most widely used drying approach [32]. Another reason is because convective dryers are always based on this mechanism and they represent the predominantly used dryers by the smallholder farmers who account for over $70 \%$ of 570 million farms worldwide [33].

Drying kinetics are frequently used to describe the microscopic and macroscopic mechanisms of mass, heat and momentum transfer during the drying process. It is greatly influenced by factors such as thermodynamic conditions, types of dryer and physiognomies of the materials being dried [34, 35]. Thus, drying kinetics can be used in the choice of the appropriate dryer and operating conditions for agricultural produce since the kinetics account for the removal of moisture and the influence of other variables. The removal of moisture in food with respect to the time is illustrated in Fig. 3 which is generated by plotting moisture loss against drying time. At the beginning of drying (initial period), the food sample comes in thermal equilibrium with the drying chamber after which the external moisture in the food begins to be removed (constant drying rate). Drying at this stage is mostly influenced by the drying conditions: air temperature, velocity and relative humidity. This continues until the critical moisture content is reached after which falling rate period begins. Rather than drying conditions, drying is diffusion dependent. Food particle size and matrix play significant roles at this stage [36].

Therefore, drying dynamics at each of the aforementioned stage are either influenced by the driving force which is a function of energy sources or drying diffusion which is a function of the agricultural product's tissue matrices. Details of the former in relation to energy sources are briefly discussed. The frequently adopted energy efficiency is related with the energy used for moisture evaporation at the material feed temperature which is illustrated in Fig. 4 [37]. $W, T, Y, F, X$ and $Q_{\mathrm{h}}$ symbolise air flow rates 
$\left(\mathrm{kg} \cdot \mathrm{s}^{-1}\right)$, temperature $\left({ }^{\circ} \mathrm{C}\right)$, absolute air humidity $\left(\mathrm{kg} \mathrm{H}_{2} \mathrm{O} \cdot \mathrm{kg}^{-1}\right.$ dry air), feed rate $\left(\mathrm{kg} \cdot \mathrm{h}^{-1}\right)$, material moisture content $\left(\mathrm{kg} \mathrm{H} \mathrm{H}_{2} \mathrm{O} \cdot \mathrm{kg}^{-1}\right.$ dry material) and energy supplied to the drying air $\left(\mathrm{kJ} \cdot \mathrm{h}^{-1}\right)$, respectively.

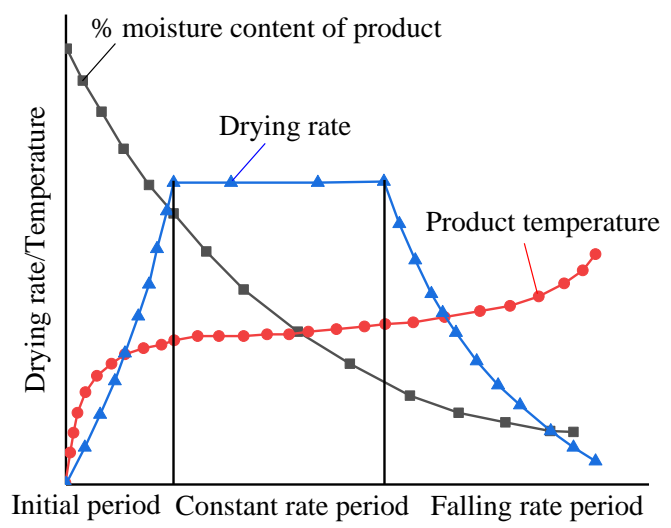

Fig. 3. Food drying curve [36].

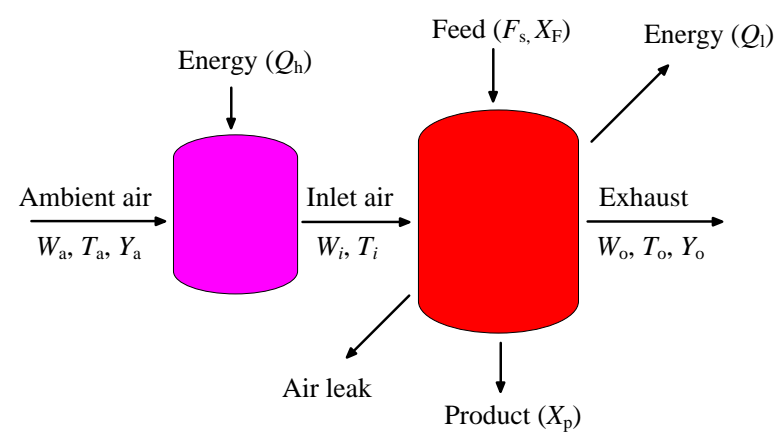

Fig. 4. Representation of the convective dryer [37].

The general thermal efficiency of the dryer can be evaluated as equation 1

$$
\boldsymbol{\mu}=\frac{\text { energy for evaporation }}{\text { total energy supplied }}
$$

However, total energy supply to the dryer i.e. summation of the latent energy of the ambient air is mainly influenced by the later operating process which is determined by energy sources such as biomass, biogas, solar, geothermal or recirculation. Efficiency assessment methods of some natural convective systems are presented in Table 1.

Table 1. Thermal efficiencies of convective dryers using different energy sources.

\begin{tabular}{ccc}
\hline Energy source & Efficiency analysis & References \\
\hline Solar dryer & $\mu_{t h}=\frac{\dot{m}_{w} l_{v}}{A_{c} I} \times 100 \%$ & {$[38,39]$} \\
Biogas & $\mu_{t h}=\frac{\dot{\mathrm{m}}_{w} l_{v}}{\dot{\mathrm{m}}_{\text {biogas }} \times L H V_{\text {biogas }} \times \mu_{\text {biogas stove }}} \times 100 \%$ & {$[40]$} \\
Biomass & $\mu_{t h}=\frac{\dot{\mathrm{m}}_{w} l_{v}}{\dot{\mathrm{m}}_{f w} \times L H V_{f w} \times \mu_{f w-\text { stove }}} \times 100 \%$ & [41] \\
\hline
\end{tabular}




Geothermal $\quad \mu_{t h}=\frac{\dot{\mathrm{m}}_{w} l_{v}}{Q_{g e o} \mu_{e x}} \times 100 \% \quad[42,43]$

\section{Hybrid drying}

Sun acts as the heat source for solar drying. It can be achieved through natural sun drying where materials are placed under direct sunlight without shielding from the unfriendly climatic conditions [44]. It is widely acknowledged that solar drying could be classified into direct drying and indirect drying [45]. For direct solar drying, materials are placed in a container, which are covered with a transparent plastic or glass and dried by solar irradiation absorbed through the cover. In regard of indirect drying, the air is heated by solar energy and subsequently used in drying or mixed drying which involves the combination of solar radiation incidence and heated air for materials drying. Due to time discrepancy of solar energy, drying is characterized as discontinuous operation in case of sunsets or on cloudy days. Thus, a major deficiency of solar drying systems is its intermittence, which inevitably has a negative impact on the quality of dried products $[46,47]$. Comparably, hybrid solar systems could solve this problem by utilizing either an additional source of heat energy or thermal energy storage (TES).

For different energy sources, Lopez-Vidane et al. [48] studied a solar-liquid petroleum gas (LPG) hybrid dryer. The experiments were performed with tomato while the dryer was operated under the condition of LPG, solar and hybrid mode, respectively. Results demonstrated that drying efficiency and drying times are $45 \%$ with 15 hours, $15 \%$ with 28 hours and $33 \%$ with 18 hours under the condition of LPG, solar and hybrid mode. Compared with LPG system, the reduced efficiency in hybrid mode was attributed to the system's intermittence. A typical solar-desiccant hybrid dryer was studied by Misha et al., which was indicated in Fig. 5 [49]. Hot water was then used for the generation of desiccant. Electrical heater was also added to the system which was used as the supplementary when there was no sunlight. It was demonstrated that the drying time was reduced from $20.75 \mathrm{~h}$ to $15.75 \mathrm{~h}$ i.e. about $24 \%$ by using this drying system. 


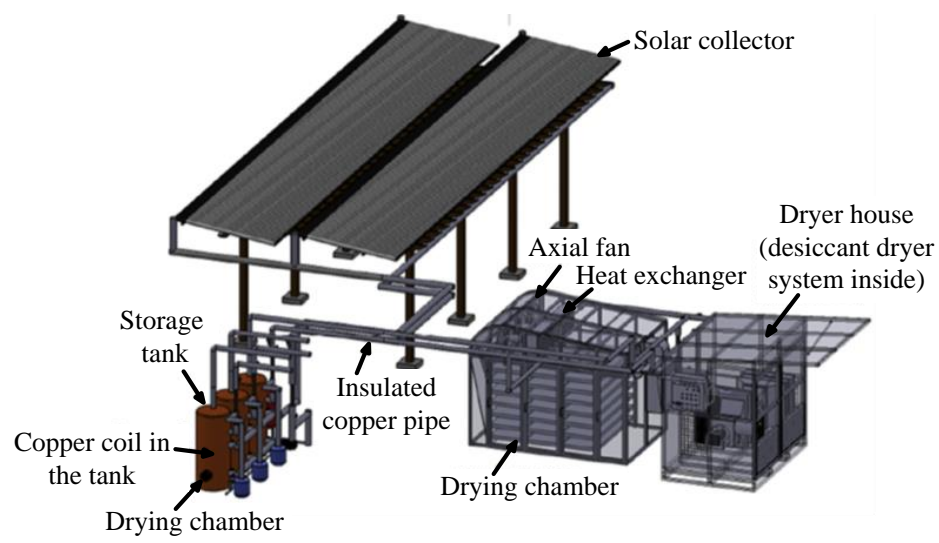

Fig. 5. A typical solar-desiccant hybrid dryer [49].

Solar photovoltaic (PV) and solar thermal collectors had equally been combined with heat and electricity storage for hybrid dryer to offset the shortcomings of solar systems. Ceylan et al. [50] designed a solar photovoltaic and thermal (PV/T) system in which a spherical shaped material was filled with paraffin wax. The system was covered with PV cells and placed at the focal point of a rectangular solar collector. The spherical cells were then placed on a box that house fan and gel accumulator (electrical storage). The box was subsequently placed on the greenhouse dryer. Heat generated by solar concentrator was used to heat the drying air and also stored in paraffin wax. Electric energy produced by PV cells was used to drive drying air while part of the electricity was also stored in the gel accumulator. This arrangement ensured continuous drying even without sunshine. However, the overall thermal energy gain was observed to be inversely proportional to solar radiation. This phenomenon was more pronounced during falling rate period when additional energy does not enhance proportional rate of moisture removal. This was because migration rates of bonded water from the cells of drying agriculture product becomes lowered during this time, and addition of energy from sunlight does not translate to an equivalent rate of water evaporation. In addition, drying air recirculation has been found to be an effective mean of reducing the effects of solar energy intermittency for the drying of some crops when using solar dryers. Mokhtarian et al. [51] investigated the effects of drying air recirculation on the drying rates and quality of pistachio nuts. Drying was performed under shade, sun drying, solar drying, and recirculation solar drying. Drying times of 48, 19, 16, 13 hours were reported for the aforementioned drying modes. It was found that air recirculation reduced drying time by $19 \%$. The nuts dried with air recirculation had the lowest shrinkage, colour change and shell splitting with the highest sweetness and roasting flavour remained. The recovered heat from flue gas of a biomass-solar hybrid dryer was used by Yassen and Al-Kayiem to power a supplementary dryer for drying red chilli [52]. Drying efficiency was then increased from $9.9 \%$ to $12.9 \%$. 
A innovative 5 tons solar-biomass hybrid dryer was constructed and accessed for maize as indicated in Fig. 6 [53]. The dryer utilized greenhouse effect for drying and air circulation was ensured with the use of a solar PV powered fan. Corn cobs were used in the drying furnace which heated the drying air via a heat exchanger. Circulation was aided with the use of another solar powered blower. The dryer was capable of drying 12,923 bags of maize per year and had a payback period of 2 years. Similarly, Borah et al. [54] assessed a hybrid solar-biomass convective dryer for drying turmeric (Curcuma Longa L). A compound parabolic solar collector with partial sun tracking was used on one side while the other side comprised of a detachable biomass combustion chamber. A wind turbine was fixed over the drying chamber to enhance air circulation. Temperature inside the dryer was observed to vary between $55^{\circ} \mathrm{C}$ and $60^{\circ} \mathrm{C}$. The dryer was able to dry turmeric from the initial moisture content of $831.09 \%$ dry basis (d.b.) to $6.68 \%$ in 14 hours as against 25 hours recorded for the open sun drying. Moreover, drying of turmeric in the integrated drying system had little effect on the curcumin content of the turmeric.

In the same vein, Amer et al. [55] investigated a hybrid electric heater-solar dryer equipped with water storage. The system was mainly solar driven but assisted with electric heater which was used after sunset or bad weather days. The use of water storage ensured continuous drying after sunset. During storage water mode, if temperature of the drying air was not enough to provide the expected temperature gradient, the electric heater was used to complement it. Besides, about $65 \%$ of the drying air was recirculated to enhance the system's efficiency. The dryer was able to reduce the moisture content of banana from $82 \%$ to $18 \%$ wet base (w.b.) in 8 hours while a similar experiment under open sun drying had $62 \%$ moisture content after 8 hours of drying.

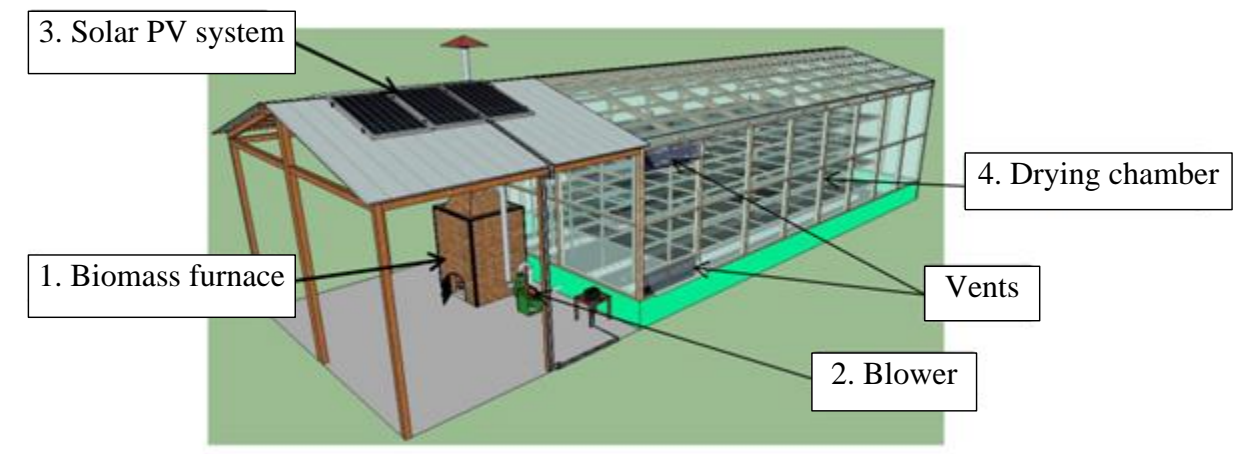

Fig. 6. Solar-biomass hybrid grain dryer [53].

Some recent works on the sustainable hybrid drying systems for agricultural products are selected and presented in Table 2. It is worth noting that most selected studies of hybrid drying for agricultural 
product focus on reduction of drying times, which are at least reduced by $15 \%$. Comparably, some scanty studies also combine quality assessment with energy efficiency. Most of these works seem technically feasible, but affordability and reliability in context of poor rural dwellers remain challenging. The pace of deployment for these drying techniques in rural areas is very slow. Thus, more research studies are desirable to be concentrated on cheaper, reliable and affordable drying systems when considering the agricultural product drying in rural areas. Most hybrid dryers studied incorporate LPG or electric heaters. It is quite difficult to obtain LPG in most isolated communities. Even if LPG is available, it is always too expensive to be used for a profitable drying.

Besides, most rural settings do not have regular supply of electricity. A suitable solution would have been the use of electricity generated from renewable sources. Electric heaters are still big consumers of electricity and their requirements may be difficult to meet with the current costs of renewable energy systems. Therefore, deployment of LPG and electric heaters may be greatly limited by these factors. Increased efforts on sustainable biomass based heat source could be a viable option for remote communities. This will also help to reduce carbon emissions associated with the use of fossil fuels which is of global concern in reducing trends of climate change.

Table 2. Selected studies on sustainable hybrid solar drying for agricultural product.

\begin{tabular}{|c|c|c|c|}
\hline Drying method & Agro-product & Research findings & Ref. \\
\hline $\begin{array}{l}\text { Solar with latent heat } \\
\text { storage }\end{array}$ & Mint leaves & $\begin{array}{l}\text { Drying continues 5-6 hours after sunset; } \\
\text { Payback period is less than two years. }\end{array}$ & {$[46]$} \\
\hline Solar-LPG & Pineapple & $\begin{array}{l}\text { Drying times are reduced from } 8.0-8.8 \text { hours to } \\
66.0-6.8 \text { hours. }\end{array}$ & {$[56]$} \\
\hline Solar-LPG & Tomato & $\begin{array}{c}\text { Drying times of } 15 \text { hours, } 28 \text { hours and } 18 \\
\text { hours are noted for LPG, solar and hybrid mode } \\
\text { respectively. }\end{array}$ & {$[48]$} \\
\hline $\begin{array}{l}\text { Solar-desiccant-electric } \\
\text { heater }\end{array}$ & $\begin{array}{l}\text { Kenaf core } \\
\text { fibre }\end{array}$ & Drying time is reduced by $24 \%$. & [49] \\
\hline $\begin{array}{c}\text { Solar PV/T with TES } \\
\text { system }\end{array}$ & $\begin{array}{l}\text { Spinach } \\
\text { leaves }\end{array}$ & $\begin{array}{l}\text { Drying continues several hours after sunset; } \\
\text { Paraffin wax ensures the reduced temperature } \\
\text { rise of PV units. }\end{array}$ & {$[50]$} \\
\hline Biomass-solar & Cashew nut & $\begin{array}{c}\text { Drying is completed in } 7 \text { hours with forced } \\
\text { hybrid system with system efficiency of } 5.08 \% \text {; } \\
\text { Drying time of } 9 \text { hours with } 3.17 \% \text { is recorded } \\
\text { for natural convection. }\end{array}$ & {$[57]$} \\
\hline Solar-water storage & Tomato & $\begin{array}{l}\text { Time savings of } 56.25 \% \text { is for the hybrid solar } \\
\text { dryer when compared to sun-drying. } \\
\text { Compared with commercially available dried } \\
\text { tomato available in the market, better quality is } \\
\text { obtained especially in terms of ascorbic acid, } \\
\text { lycopene and flavonoids contents. }\end{array}$ & {$[58]$} \\
\hline Solar-electric heater & Tomato & $\begin{array}{l}\text { Use of solar energy results in 6.6-12.5\% energy } \\
\text { savings. } \\
\text { Non-enzymatic browning, Maillard reaction }\end{array}$ & {$[59]$} \\
\hline
\end{tabular}




\begin{tabular}{|c|c|c|c|}
\hline & & $\begin{array}{c}\text { and lycopene degradation are observed in the } \\
\text { dried tomato. }\end{array}$ & \\
\hline Solar-biomass & Yam chips & $\begin{array}{l}\text { Drying rate of } 0.0142 \mathrm{~kg} \cdot \text { hour }^{-1} \text { is recorded for } \\
\text { the hybrid mode when compared with } 0.00732 \\
\mathrm{~kg} \cdot \text { hour }^{-1} \text { noted for single mode. }\end{array}$ & {$[60]$} \\
\hline Solar-biomass & $\begin{array}{l}\text { Okra, } \\
\text { groundnut and } \\
\text { yam chips }\end{array}$ & $\begin{array}{l}\text { Efficiency of the dryer varies with crops dried; } \\
\text { Energy efficiency varies from } 0.23 \% \text { to } 16.04 \% \\
\text { for okra, groundnut and cassava chips drying. }\end{array}$ & {$[61]$} \\
\hline $\begin{array}{l}\text { Solar dryer with air } \\
\text { recirculation }\end{array}$ & pistachio nuts & $\begin{array}{l}\text { Air recirculation produces better product } \\
\text { quality; Drying time is reduced by } 19 \% \text {. }\end{array}$ & {$[51]$} \\
\hline $\begin{array}{l}\text { Heat recovery from a } \\
\text { hybrid solar-biomass } \\
\text { convective dryer }\end{array}$ & Red chilli & Drying efficiency is from $9.9 \%$ to $12.9 \%$. & {$[52]$} \\
\hline $\begin{array}{c}\text { Solar-biomass hybrid } \\
\text { dryer }\end{array}$ & Maize & $\begin{array}{c}\text { It can dry } 12,923 \text { bags of maize per year with } 2 \\
\text { years payback period. }\end{array}$ & {$[53]$} \\
\hline $\begin{array}{l}\text { Solar-biomass wind } \\
\text { turbine hybrid dryer with } \\
\text { partial tracking }\end{array}$ & Turmeric & $\begin{array}{l}55-60^{\circ} \mathrm{C} \text { is observed inside the drying chamber; } \\
\text { Moisture content is reduced from } 831.09 \% \\
\text { (d.b.) to } 6.68 \% \text { in } 14 \text { hours against } 25 \text { hours } \\
\text { observed for the open sun drying. }\end{array}$ & {$[54]$} \\
\hline $\begin{array}{l}\text { Electric heater-solar dryer } \\
\text { with air recirculation }\end{array}$ & Banana & $\begin{array}{l}\text { Moisture content is reduced from } 82 \% \text { to } 18 \% \\
\text { (w.b.) in } 8 \text { hours when compared to } 62 \% \\
\text { moisture content for open sun drying. }\end{array}$ & {$[55]$} \\
\hline
\end{tabular}

\section{Waste/Recovered heat for food drying}

Another approach that has been extensively researched in sustainable drying of agricultural product is the use of waste or recovered heat. The heat that would have been lost through exhaust or cooling system could serve as an excellent source of heat for drying if the heat could be recovered. Such system is called cogeneration i.e. CHP or tri-generation system when combined with cooling units [62]. Some case studies are presented as follows: Aziz et al. [63] redesigned an existing rice milling plant where its kerosene burner was replaced with the recovered heat exhaust gas from a $120 \mathrm{kVA}$ diesel engine. The new configuration was able to dry 2 tons of paddy rice at $53^{\circ} \mathrm{C}$ in 8 hours. Samadi et al. [64] also investigated the application of CHP system for drying of apple slices, and a typical schematic was demonstrated in Fig. 7. Exhaust gas of a $2 \mathrm{~kW}$ natural gas driven engine was used for drying apple slices with the thickness of $3 \mathrm{~mm}, 5 \mathrm{~mm}$ and $7 \mathrm{~mm}$, respectively. Drying process was conducted under conditions of $25 \%, 50 \%, 75 \%$ and $100 \%$ engine load. It was found that the minimum specific energy consumption could be obtained at $75 \%$ engine load and $3 \mathrm{~mm}$ product's thickness. This could be mainly attributed to the lower exhaust heat and reduction of air/fuel ratio for complete combustion at $25 \%$ and $100 \%$ engine load. Thus, the highest energy efficiency of the system was $16 \%$ at $75 \%$ engine load. 


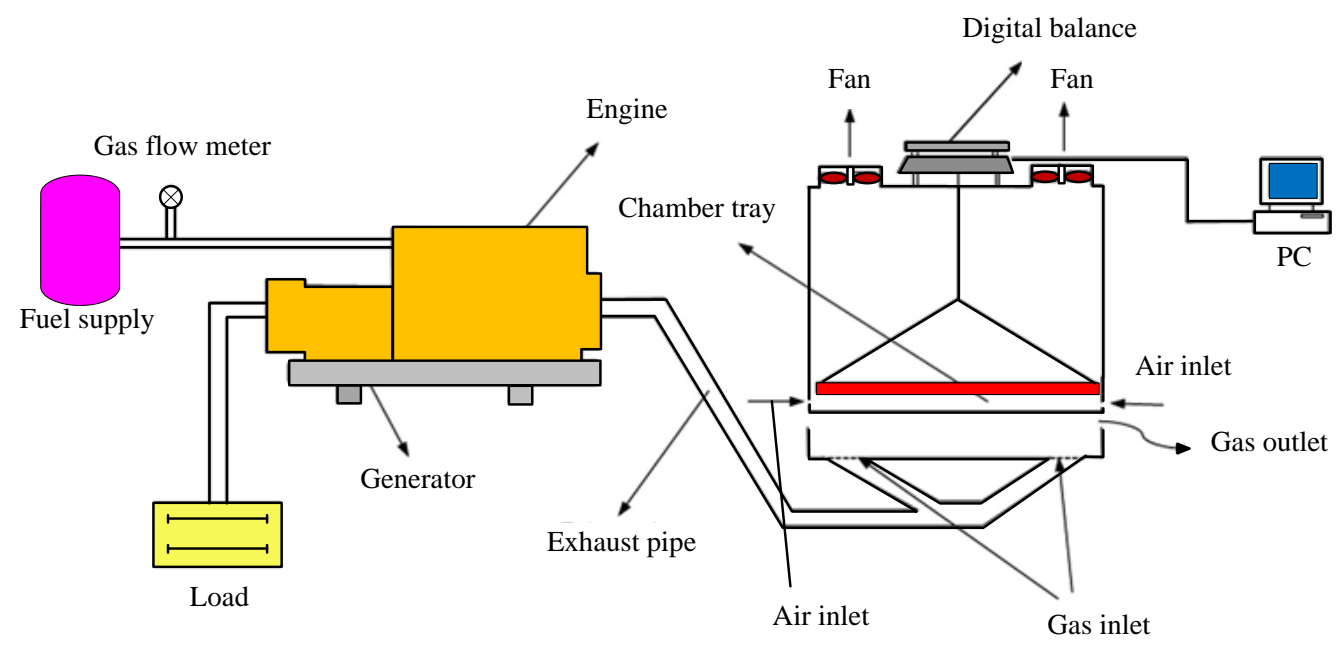

Fig. 7. Experimental set up of CHP for drying of apple slices [64].

Similarly, a $1.6 \mathrm{~kW}$ gasoline engine powered flat deep bed dryer was assessed by Basunia and Abe [65]. Waste heat from the engine's cooling system was used to heat up drying air. The recovered heat was enough to supply $3.15 \mathrm{MJ} \cdot \mathrm{kg}^{-1}$ energy required for moisture removal. Consequently, the configuration was able to dry $480 \mathrm{~kg}$ of paddy rice per batch of 22 hours even during rainy days when humidity is relatively high. Akhte et al. [66] similarly investigated a cross-flow heat exchanger for heat recovery from exhaust gas of a diesel engine. Ambient air was used for heat recovery and subsequently adopted for drying the paddy rice. The designed system was able to reduce the moisture content from $26.1 \%$ to $15 \%$ within an hour drying to $6.6 \mathrm{~kg}$ paddy rice.

By using diesel and biogas dual fuel, Cacua et al. [40] experimentally examined a tri-generational system for cooling, drying and power as indicated in Fig. 8. Heat was recovered from engine's exhaust and used to drive an absorption refrigeration unit and a convective tray dryer, which was used for drying peppermints. At the engine's full load, improved energy efficiencies of $40 \%$ and $31 \%$ were reported under the conditions of diesel and dual fuel mode, respectively. It is significant improvements when compared with $23 \%$ and $18 \%$ obtained when the system is operated under single generation mode. Also worth noting that a maximum 50\% diesel substitution was achieved. Elisante et al. [67] studied a fish cabinet dryer that was driven with heat from waste oil burner. The dryer consumed $2.4 \mathrm{~L} \cdot$ hour $^{-1}$ of waste engine oil, which was capable of drying 1 ton $\cdot$ day $^{-1}$ of fish at $250 \mathrm{~kg} \cdot$ batch $^{-1}$ during 2 hours drying process. 


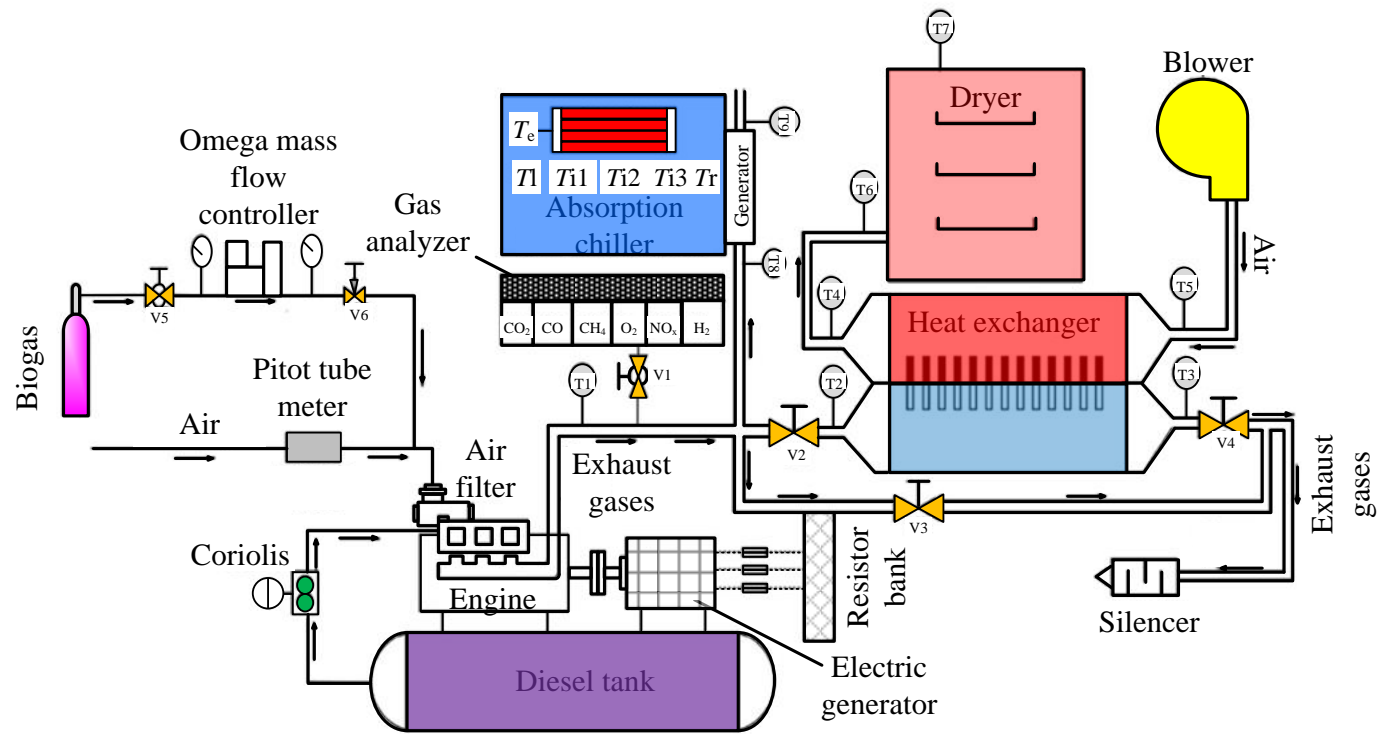

Fig. 8. Experimental set up for a combined cooling, drying and power generation system [40].

A combined cooling and drying system was evaluated by Sivakumar et al. [68], and a $10.5 \mathrm{~kW}$ vapour absorption ammonia-water chiller was adopted. Heat was recovered from the exit of absorber and condenser with a temperature from $43^{\circ} \mathrm{C}$ to $53^{\circ} \mathrm{C}$, which was subsequently used as heat input for a 5 $\mathrm{kg} \cdot$ hour $^{-1}$ vertical bin grain dryer. The dryer was used to dry Nylon Sago, and COP of the combined system reportedly varied from 1.4 to 1.8 depending on the temperature of heat sink. Luo et al. [69] investigated retrofitting of Dengwu geothermal power plant using heat recovery. The proposed configuration utilised recovered heat for space cooling and drying of longan fruits. The discharged geothermal waste water at $72^{\circ} \mathrm{C}$ was used to drive a $\mathrm{LiCl}-\mathrm{H}_{2} \mathrm{O}$ absorption system for cooling as well as heating of drying air for a re-circulatory cabinet dryer. Payback time of the retrofitting was evaluated to be 1.85 years while the system efficiency was increased from $3.73 \%$ for single flash to $24.6 \%$ for the integrated system. Table 3 illustrates some selected research studies on the combined power and drying systems by using various recovered heat sources. It is widely acknowledged that CHP is a matured technology that is capable of delivering not only electricity to the rural households but also heat for domestic use and processing of agricultural products. To achieve poverty reduction, food security and clean energy delivery as entrenched in the sustainable development goals, provision of clean energy must be synchronised with basic food processing and preservation. This is achievable with CHP technology. Unfortunately, it has not been given enough attentions in this regards. Therefore, design optimisation, 
technical evaluation and socioeconomic analysis of combined cooling, drying and power generation systems need to be valued. Importantly, more research studies are required to be carried out based on policy guidance, requirements and matching the specific needs of different local settings.

Table 3. Recent works on combined power and drying systems.

\begin{tabular}{|c|c|c|c|}
\hline Drying method & Agro-product & Remarks & Ref. \\
\hline $\begin{array}{l}\text { Biomass (Corn } \\
\text { Stover) CHP }\end{array}$ & Corn grain & $\begin{array}{c}\text { 20-year net present value (NPV) cost saving is } \$ 65,523 \\
\text { with } 14.3 \text { years payback period noted for small dryer; } \\
\text { Positive NPV with } 7.5 \text { years payback is for a bigger } \\
\text { dryer. }\end{array}$ & {$[70]$} \\
\hline $\begin{array}{l}\text { Biomass (cassava } \\
\text { waste) gasification }\end{array}$ & $\begin{array}{l}\text { Cassava flour } \\
\text { processing }\end{array}$ & $\begin{array}{c}\text { Positive NPV and payback period is less } 3 \text { years for } \\
\text { gasification. }\end{array}$ & {$[71]$} \\
\hline Diesel CHP & Paddy rice & $\begin{array}{l}\text { Moisture content of } 6.6 \mathrm{~kg} \text { paddy rice is reduced from } \\
26.1 \% \text { to } 15 \% \text { in } 1 \text { hour. }\end{array}$ & [66] \\
\hline Diesel CHP & Paddy rice & 2 tons of paddy rice are dried at $53^{\circ} \mathrm{C}$ in 8 hours; & [63] \\
\hline $\begin{array}{l}\text { Diesel-biogas dual } \\
\text { fuel tri-generation }\end{array}$ & Peppermints & $\begin{array}{c}\text { Energy efficiency of } 40 \% \text { and } 31 \% \text { are stated for single } \\
\text { and dual fuel mode. } \\
\text { Maximum diesel substitution of } 50 \% \text { is recorded; }\end{array}$ & {$[40]$} \\
\hline Gasoline CHP & Paddy rice & $\begin{array}{c}\text { Recovered heat supplied is required } 3.15 \mathrm{MJ} \cdot \mathrm{kg}^{-1} \text { for } \\
\text { drying; } 480 \mathrm{~kg} \text { of paddy rice per batch of } 22 \text { hours is } \\
\text { dried. }\end{array}$ & {$[65]$} \\
\hline $\begin{array}{l}\text { Geothermal power } \\
\text { plant retrofitting }\end{array}$ & Longan fruit & $\begin{array}{l}\text { Payback period of } 1.85 \text { years is noted; } \\
\text { Efficiency is increased from } 3.73 \% \text { to } 24.6 \% \text {. }\end{array}$ & [69] \\
\hline $\begin{array}{l}\text { Heat recovery from } \\
\text { the condenser and } \\
\text { absorber units of } \\
10.5 \mathrm{~kW} \text { ammonia- } \\
\text { water chiller }\end{array}$ & Nylon sago & $\begin{array}{l}\text { Exit air temperature from absorber and condenser varies } \\
\text { between } 43^{\circ} \mathrm{C} \text { and } 53^{\circ} \mathrm{C} \text { and is able to dry } 5 \mathrm{~kg} \cdot \text { hour }^{-1} \text { of } \\
\text { nylon sago. } \\
\text { COP varies between } 1.4 \text { and } 1.8 \text { which is dependent on } \\
\text { ambient temperature. }\end{array}$ & [68] \\
\hline $\begin{array}{l}\text { Low grade heat } \\
\text { from a power plant }\end{array}$ & Wood pine & $\begin{array}{c}\text { Waste heat from a } 100 \mathrm{MW} \text { power plant is used to dry } \\
\text { wood pine chips for a subsequent } 40 \mathrm{MW} \text { plant. } \\
\text { Payback period is less than } 3 \text { years but subject to fuel } \\
\text { prices. }\end{array}$ & [72] \\
\hline $\begin{array}{l}\text { Natural gas CHP } \\
\text { system }\end{array}$ & Apple slices & $\begin{array}{c}\text { The highest system's efficiency could reach } 16 \% \\
\text { increment at } 75 \% \text { engine load. }\end{array}$ & {$[64]$} \\
\hline Waste black oil & Fish & $\begin{array}{l}\text { The dryer is able to dry } 1 \text { ton } \cdot \text { day }^{-1} \text { of fish at } 250 \\
\mathrm{~kg} \cdot \text { batch }^{-1} \text { of } 2 \text { hours drying time. }\end{array}$ & {$[67]$} \\
\hline
\end{tabular}

\section{Phase change materials used for food drying}

Shortcomings of some renewable energy technologies such as solar systems which suffer from intermittency, irregularities of electricity availability in some regions and quest for systems efficiency are some of the drivers to the adoption of TES. TES is essential and effective to many RET systems since it has the ability to adjust temporal mismatches between loads and variable energy sources [73]. TES can be generally divided into sensible heat, latent heat and thermochemical reaction, which store heat in well-insulated fluids or solids as a change in internal energy [74]. In spite of high energy density, thermochemical energy storage is rarely applied in the drying of agriculture products due to its unstable and uncontrollable characteristics [75]. Many research studies have been carried out on sensible heat 
storage for food drying. However, the limitations of sensible heat storage are the relatively low energy density and requirements of large heat storage volume [76]. Comparably, latent heat storage by using phase change material (PCM) could be a compromise for RET drying of agriculture products. Thermal energy transmission takes place in PCMs when the materials change from solid to liquid, from liquid to gas, etc. [77]. The stored heat has been extensively researched in drying of agricultural products which has been proved to, not only reduce the effects of fluctuating natures of renewable energy systems, but also control and stabilise drying temperature. PCMs are able to store 5-14 times more heat per unit volume than that of sensible heat storage materials, which further reduce the volume in real application [78]. Heat stored by a PCM can generally be expressed as equation 2 [79].

$$
Q_{s l}=\int_{\mathrm{T}_{\mathrm{i}}}^{\mathrm{T}_{\mathrm{pc}}} C_{\mathrm{s}} \mathrm{d} T+\Delta H_{1}+\int_{\mathrm{T}_{\mathrm{pc}}}^{\mathrm{T}_{\mathrm{f}}} C_{1} \mathrm{~d} T
$$

where $Q_{\mathrm{sl}}$ is the sensible and latent heat stored by the material, $C_{\mathrm{s}}$ is the average specific heat between $T_{1}$ and $T_{\mathrm{pc}}, C_{\mathrm{l}}$ is the average specific heat between $T_{\mathrm{pc}}$ and $T_{2}, \Delta H_{1}$ is the latent heat of fusion during phase changing process while $T_{\mathrm{i}}, T_{\mathrm{pc}}$ and $T_{\mathrm{f}}$ represent the initial, phase change and final temperatures, respectively.

In regard of PCM for food drying, phase changing temperature should be much higher. Thus, PCM for the drying of agriculture products could be generally classified into paraffin and non-paraffin materials e.g. hydrates. Due to good properties of paraffin such as high safety and reliability, low cost and non-corrosive, it is still taking a leading role in RET drying for agriculture products. Some representative examples are further illustrated as follows: Pati et al. [80] studied usage of paraffin wax as TES material for the drying of ginger slices. As presented in Fig. 9, biomass was burnt on the furnace, and heat being carried away by the flue was recovered for drying and partially stored in PCM. The dryer was able to reduce the moisture content of $2 \mathrm{~mm}$ ginger slices from $88-90 \%$ (w.b.) to $11-12 \%$ in 5.5 hours. It was demonstrated that PCM could reduce the quantity of biomass and control drying temperature. The quality of dried ginger was better by using PCM. Similarly a novel crop dryer was studied by Jain and Tiwari [46] for drying of leafy herbs which was illustrated in Fig. 10. The dryer was composed of flat plate solar absorber, packed TES bed containing $50 \mathrm{~kg}$ PCMs and drying chamber. It was observed that temperature inside the drying chamber was $6^{\circ} \mathrm{C}$ above ambient temperature 5-6 hours after sunset while the rate of return and payback period were $65 \%$ and 1.57 years, respectively.

Using paraffin wax for solar TES, a solar-electric resistance hybrid dryer with $70-80 \%$ drying air recirculation was examined for mushroom drying by Alejandro et al [81]. The use of PCM reportedly 
resulted in 10-21\% reduction in electrical energy. Furthermore, an indirect solar dryer with PCM for heat storage was experimentally investigated by Shalaby and Bek [82] for drying of Ocimum Basilicum and Thevetia Neriifolia. Compared with ambient temperature, a temperature increase of $2.5-7.5^{\circ} \mathrm{C}$ was recorded 5 hours after sunset in the system with energy storage. Besides, Berroug et al. [83] examined the use of $\mathrm{CaCl}_{2} \cdot 6 \mathrm{H}_{2} \mathrm{O}$ for a north wall thermal storage greenhouse dryer in Marrakesh climate. The findings indicated that a $6-12^{\circ} \mathrm{C}$ higher temperature can be obtained at night time by using $32.4 \mathrm{~kg}$ of PCM per square meter of the greenhouse ground surface area.

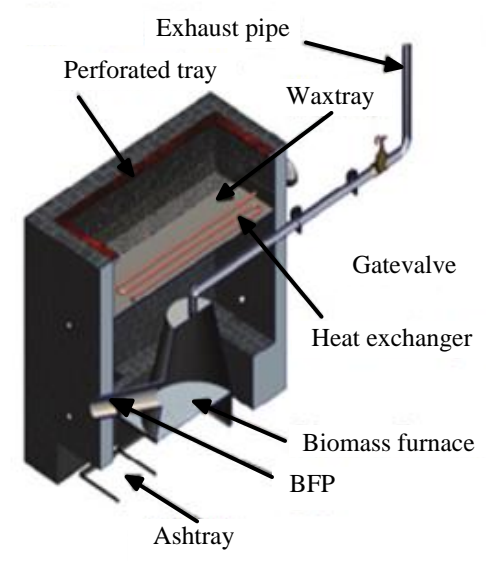

(a)

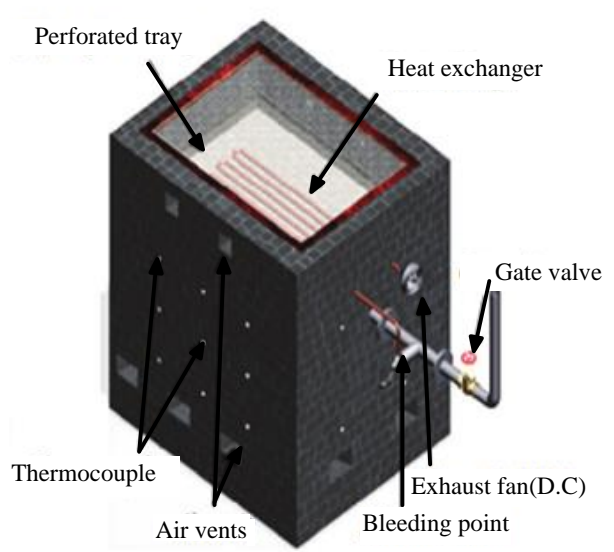

(b)

Fig. 9. Biomass dryer with PCM (a) sectional view of the natural conventional dryer; (b) isometric

view of the natural conventional dryer [80].

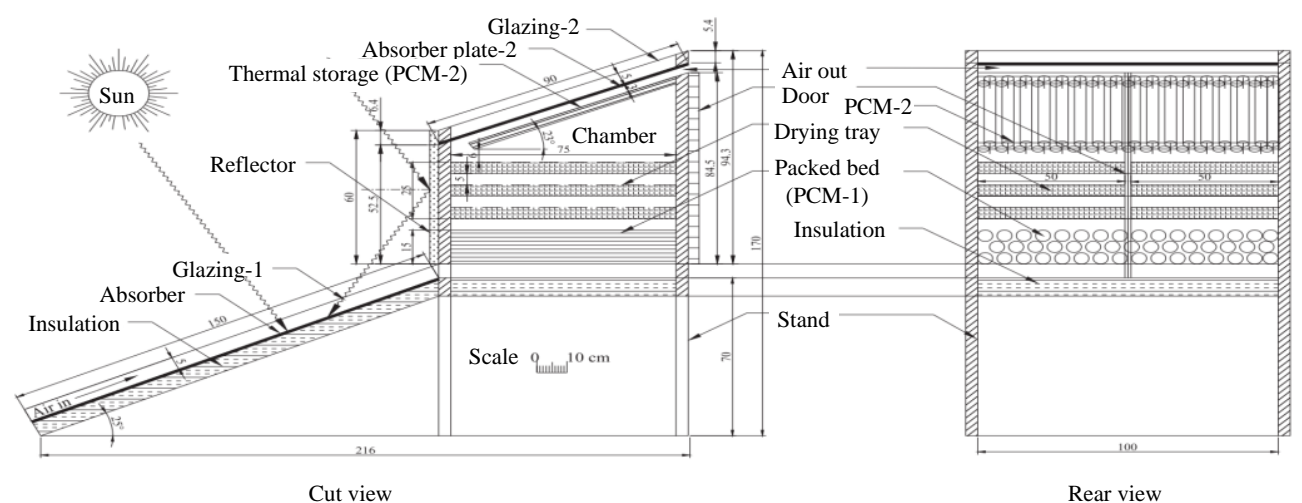

(a) 


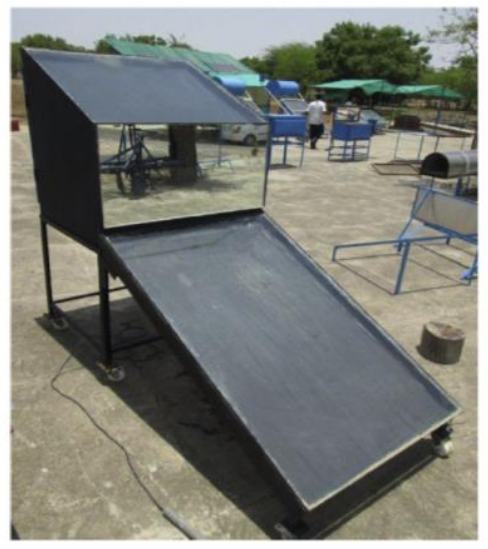

(b)

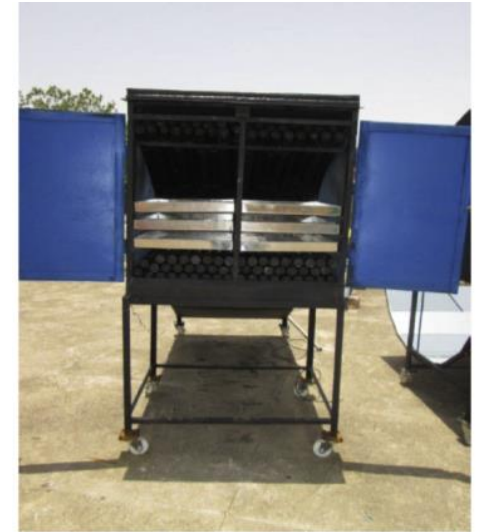

(c)

Fig. 10. Flat plate solar crop dryer with TES (a) schematic of the system; (b) photo of the system

PCM ; (c) photo of packed PCM bed and drying trays [46].

Some selected works on drying of agricultural product by using PCMs are summarized in Table 4 with regard to investigation method, PCM and research findings. Thermal analysis, simulation and experiment are investigated separately or jointly. Paraffin wax and hydrates could be candidates for food drying. Some desiccants e.g. silica-gel or zeolite are also included in this table for comparison, which could be classified into chemisorption energy storage. It is demonstrated that the use of PCMs can improve the overall quality and efficiency of food drying. Currently, sensible heat storage could be a candidate if the required volume and mass are not limited. Considering PCMs, more novel materials should be developed for the drying of agriculture products. Some other water sorbents e.g. metal organic frameworks (MOF) could also be attempted for chemical TES. The combination of these TES technologies is also feasible in the future.

Table 4. Summarization of some selected works on food drying by using PCMs.

\begin{tabular}{|c|c|c|c|c|}
\hline $\begin{array}{l}\text { Investigation \&dry } \\
\text { methods }\end{array}$ & Agro-product & PCM & Research findings & Ref. \\
\hline $\begin{array}{l}\text { Experiment\& } \\
\text { Indirect forced } \\
\text { convection }\end{array}$ & Sweet potato & Paraffin wax & $\begin{array}{l}\text { The energy savings are } 40 \% \text { and } 34 \% \text { with } \\
\text { inlet ambient air velocity of } 1 \mathrm{~m} \cdot \mathrm{s}^{-1} \text { and } 2 \\
\mathrm{~m} \cdot \mathrm{s}^{-1} \text {, respectively. }\end{array}$ & [84] \\
\hline $\begin{array}{l}\text { Simulation\& } \\
\text { Greenhouse dryer }\end{array}$ & Plants & $\mathrm{CaCl}_{2} \cdot 6 \mathrm{H}_{2} \mathrm{O}$ & $\begin{array}{l}\text { Air temperature of } 6-12^{\circ} \mathrm{C} \text { is increased at } \\
\text { night; } 10-15 \% \text { relative humidity is reduced. }\end{array}$ & [83] \\
\hline $\begin{array}{l}\text { Experiment\& } \\
\text { Indirect solar dryer }\end{array}$ & $\begin{array}{l}\text { Ocimum } \\
\text { Basilicum } \\
\text { \&Thevetia } \\
\text { Neriifolia }\end{array}$ & Paraffin wax & $\begin{array}{l}\text { Temperature of drying air is increased by } \\
2.5-7.5^{\circ} \mathrm{C} \text { up to } 5 \mathrm{~h} \text { after sunset with PCM. }\end{array}$ & [82] \\
\hline $\begin{array}{l}\text { Thermodynamic } \\
\text { analysis\&Indirect } \\
\text { solar dryer }\end{array}$ & Garlic cloves & - & $\begin{array}{l}\text { The moisture content of garlic cloves is } \\
\text { reduced from } 55.5 \% \text { (w.b.) to } 6.5 \% \text { (w.b.) } \\
\text { for } 8 \text { h. }\end{array}$ & [85] \\
\hline Experiment\& & Crop & & Thermal efficiency is $28.2 \%$; Payback time & [46] \\
\hline
\end{tabular}




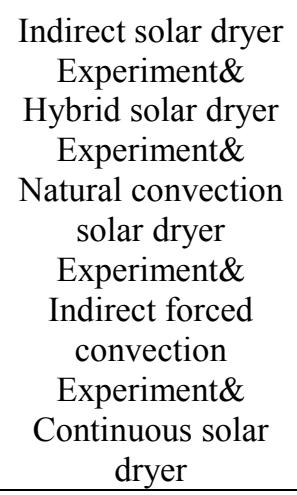

Mushrooms Paraffin wax

Ginger Paraffin wax
Green peas
and pineapple slices

Cocoa beans is 1.5 year.

Moisture content is 1.91 (d.b.). Thermal

efficiency fluctuates from $10 \%$ to $21 \%$.

The overall thermal efficiency of solar dryer could reach $22.7 \%$.

The inclusion of reflective mirror on the desiccant bed increases the drying potential by $20 \%$.

The highest temperature of drying chamber varies from $40^{\circ} \mathrm{C}$ to $54^{\circ} \mathrm{C}$, which is $9-12^{\circ} \mathrm{C}$ higher than ambient temperature.

\section{Effect of different drying methods on quality of agriculture products}

Crop drying is to ensure an increased shelf life of a material while maintaining its wholesomeness as much as possible. Most drying approaches are usually related with quality evaluation of the materials to access the impacts of drying method on taste, colour, texture, nutritional functions and other organoleptic qualities of food. Hence, balance must be sought between product quality and energy usage since both are quite significant in the drying process [89]. However, there exist conflicting evidences on quality acceptability of hybrid systems dried agricultural products. Hussein et al. [90] conducted functional and sensory analysis of tomato which was dried with a hybrid solar dryer, direct solar dryer and open sun drying. It was also compared with dried tomatoes obtained from the market. Analysis of wettability, water absorption index, solubility index, bulk density and organoleptic properties demonstrated the superiority of hybrid dried samples. Besides, Pati et al. [80] demonstrated that the organoleptic analysis of herbal mint used in their study had good colour, odour and taste. Simultaneously, recovered heat from biomass proved to be a good source of thermal energy for drying. The physiochemical properties such as total ash, acid insoluble ash, water and alcohol soluble extractives were reportedly within the quality standard of pharmaceutical industries. Additionally, Hossain et al. [58] found out that hybrid dryers produced tomato with a better quality and a $56.25 \%$ drying time savings could be achieved when compared with sun drying. Solar dried tomato had $184.24 \mathrm{mg}, 49.04 \mathrm{mg}$, and $195 \mathrm{mg}$ per $100 \mathrm{~g}$ ascorbic acid, lycopene and flavonoids in comparison with $176.7 \mathrm{mg}, 44.06 \mathrm{mg}$ and $96.7 \mathrm{mg}$ per $100 \mathrm{~g}$ of aforementioned compounds reported for the commercially available dried tomato.

Contrarily, used black oil was proposed as substitute to fossil fuel which was adopted in fish dryer burner by Elisante et al. [67]. The results of market survey and sensory analysis revealed that people only preferred their dried fish to sun-dried fish but less acceptable to smoked fish. Besides, a solar-electric hybrid dryer was researched by Reyes et al. [59]. Although the hybrid system could realize energy 
savings by $6.6-12.5 \%$, it led to an unusual redness of dried tomato, which was attributed to the collective influence of non-enzymatic browning, Maillard reaction and lycopene degradation. Nevertheless, rehydration of dried tomato was allegedly achieved in less than 15 minutes. Similarly, a hybrid solar dryer with electric resistance and paraffin wax as PCM was accessed by Reyes et al. [81]. The system demonstrated a significant energy efficiency, but the dehydrated mushrooms had an unusual darkening and shrinkage. Rehydration was completed in less than 30 minutes but rehydrated mushroom expectedly had a higher hardness when compared with fresh ones. This was mainly due to the effect of shrinkage during the drying process. Four different dryers: Biomass-solar integrated dryer, electrical oven, fluidized bed dryer and open sun dryer were assessed and compared in terms of the textural and colour drying qualities of ginger and turmeric by Borah et al. [91]. The study proved that ginger and turmeric processed in the integrated solar dryer had both minimum colour loss and crushing strength, which revealed that the hybrid dryer was superior to other dryers.

Therefore, more works are required to establish the effects of hybrid drying on quality of dried agricultural product. Optimisation of these dryers through drying operation control may require to be further explored. The works on the drying modelling especially effects of these dryers on drying rates can provide useful information. For instance, Morad et al. [92] carried out a study on solar tunnel greenhouse dryer which indicated that peppermints were better dried as leaves than as whole plant. The highest percentage volatile oil of $0.83 \%$ and $1.52 \%$ were obtained for whole plant and leaves when the system was operated at drying air flow rate of $2.10 \mathrm{~m}^{3} \cdot \mathrm{min}^{-1}$ and loading rate of $2 \mathrm{~kg} \cdot \mathrm{m}^{-2}$, respectively. These are mainly because of the effects of operating parameters on product's drying rates. Also some regions with good potentials for renewable energy hybrid drying are culturally biased towards its deployment. For instance, smoked fish and smoked meat are preferred to their dried food in most African settings $[93,94]$. This may explain the reason why $70-80 \%$ of fish consumed in country such as Ghana was smoked [95]. Thus, more findings will be required in this regard especially incorporation of local or cultural preference on design of dryers for fish and meat. Some selected works are presented in Table 5 which aim to summarize the effect of drying technologies on qualities of crops.

Table 5. Effects of different dryers on crop quality.

\begin{tabular}{cccc}
\hline Research approaches & Agro-product & Remarks & Ref. \\
\hline $\begin{array}{c}\text { Comparison of hybrid solar, direct } \\
\text { solar and open sun drying }\end{array}$ & Tomato & $\begin{array}{c}\text { Solar hybrid dried tomato has a } \\
\text { superior quality. }\end{array}$ & {$[90]$} \\
Solar hybrid dryer & Herbal mint & $\begin{array}{c}\text { Better organoleptic quality is gained; } \\
\text { Superior physiochemical properties }\end{array}$ & {$[80]$} \\
\hline
\end{tabular}




\begin{tabular}{|c|c|c|c|}
\hline Solar hybrid dryer & Tomato & $\begin{array}{l}\text { are within the quality standard of } \\
\text { pharmaceutical industries. } \\
\text { Processed tomato has a better } \\
\text { ascorbic acid, lycopene and } \\
\text { flavonoids qualities. }\end{array}$ & {$[58]$} \\
\hline Waste oil dryer & Fish & $\begin{array}{l}\text { Sun-dried is preferred with less } \\
\text { acceptability when compared to } \\
\text { smoked fish. }\end{array}$ & [67] \\
\hline Solar-electric hybrid dryer & Tomato & $\begin{array}{l}\text { Unusual redness of dried tomato is } \\
\text { observed. }\end{array}$ & {$[59]$} \\
\hline $\begin{array}{l}\text { Solar-electric hybrid dryer with } \\
\text { PCM for heat storage. }\end{array}$ & Mushroom & $\begin{array}{l}\text { Uncommon darkening and shrinkage } \\
\text { of the mushrooms are noted. }\end{array}$ & {$[81]$} \\
\hline $\begin{array}{l}\text { Comparison of hybrid biomass- } \\
\text { solar, electric oven, fluidized bed } \\
\text { dryer and open sun drying }\end{array}$ & $\begin{array}{l}\text { Ginger and } \\
\text { turmeric }\end{array}$ & $\begin{array}{l}\text { Minimum colour loss and crushing } \\
\text { strength indicate superiority of the } \\
\text { hybrid dryer to other dryers. }\end{array}$ & [91] \\
\hline Solar tunnel greenhouse dryer & Peppermint & $\begin{array}{l}\text { Better dried as leaves than as whole } \\
\text { plant is observed. }\end{array}$ & [92] \\
\hline Heat pump (HP) & Grape pomace & $\begin{array}{l}\text { Part of the bioactive properties is lost } \\
\text { in pomace samples. }\end{array}$ & [96] \\
\hline
\end{tabular}

\section{Mathematical/computational modelling approaches used for sustainable drying}

Improving dryers' efficiency, fuel consumption efficiency, waste heat utilisation and drying air recirculation are some of the most widely used approaches to sustainable drying. However, it is not only costly but also time consuming to investigate these through experiments [97]. Also worth noting that the efficiency of the drying unit can be considerably reduced by only relying on experimental drying practices without considering the mathematical requirements of drying kinetics, which will inevitably result in an increased production cost and negatively impact on the quality of dried products [98]. Thus, through modelling, some unique optimisation advantages could be obtained compared to drying experiments, e.g. a comprehensive physical insight and understanding of the drying process, a quantified heat and mass transfer flows, high sensitivity to external changes, low cost, space requirements, maintenance and technical for experiment, etc. [99]. These advantages could further improve the mass, energy and economic performance of drying process. Then the best candidate from simulation results is subsequently designed and fabricated. Computer programming software used in food drying could be categorised into the followings [100]:

[1] Calculation programs such as one used for numerical modelling e.g. SPSS, Microsoft Excel, Spreadsheet.

[2] Process simulator.

[3] Expert systems and related decision tools.

[4] Information delivery or online data base. 
[5] Auxiliary calculations such as psychometric and humidity chart.

Use of these tools are also determined by the complexity of information required by the user. These tools can be easily used for sensitivity analysis, optimisation, equipment design, sizing, scaling up and pilot scale. The commonly used simulation tools for drying are Aspen Plus, Simprosys, dryPAK, DryDSim, etc. Other tools that are not only specifically for drying but also used in drying modelling are Matlab and Microsoft Excel with Visual Basic. Aspen Dryer and DRYSCOPE are packages within Aspen Plus which are designed for drying. However, a lot of assumptions are used for simplification which are far away from practical use. This is because Aspen Plus and Aspen Hysys are designed for materials of known chemical compositions whereas chemical compositions of food and agricultural materials are not static as it changes with species, climatic conditions and water composition. Another limitation of Aspen Plus in drying is that it assumes constant rate drying kinetics [101] whereas drying kinetics are dependent on drying time which are not static during drying processes. It is based on flash calculation of temperature, pressure and enthalpy [102] whereas state variables such as absolute and relative humidity, wet bulb and dew point temperature are required for the evaluation and optimisation of drying systems.

Matlab was employed to solve Crank-Nicholson model for three dimensional conduction equation of a greenhouse dryer by Yeboah [103]. The model was used to achieve drying optimisation, which was subsequently validated with experimental drying of cocoa beans. Moisture content was reduced from 50\% to $7 \%$ within 7 days. Similarly, different shapes of blanched and un-blanched potato slices were investigated in a tray dryer by Olawale and Omole [104] with temperature range between $50^{\circ} \mathrm{C}$ and $80^{\circ} \mathrm{C}$ using hot air at a flow rate of $2.5 \mathrm{~m} \cdot \mathrm{s}^{-1}$ and $10 \%$ relative humidity. The results of drying experiments were fixed into eight known drying models and analysed by using Matlab. Drying rate, at constant temperature, expectedly decreased with the increase of thickness while page model allegedly predicted potato drying perfectly.

Simprosys is a Windows-based process simulation tool which can be used for flowsheet design and evaluation of drying and evaporation units [102]. An alternative configuration to an existing lignite fired power plant was presented by $\mathrm{Xu}$ et al. [105]. The new configuration suggested replacing water cooling condenser with air cooling e.g. the low grade heat from heat sink at $45^{\circ} \mathrm{C}$ was proposed to be used for lignite drying. The proposed configuration was evaluated with Simprosys software. The pre-drying of lignite reportedly led to increased power output by $1.3 \%$ which subsequently reduced levelised cost of electricity generation from $\$ 47.3 \cdot \mathrm{MWh}^{-1}$ to $\$ 45.1 \cdot \mathrm{MWh}^{-1}$. Similarly, Mujumdar and Zhen-Xiang [106] 
investigated modelling of combustion drying process in a burner. The effects of pressure and combustion gas humid properties were investigated by using Simprosys. It was concluded that the moisture carrying property of air and combustion gas was dependent on the working pressure.

Computational Fluid Dynamic (CFD) is one of the widely used software in advance modelling of drying systems either in the optimisation of the existing dryers or design of novel systems for improving energy and resource efficiency. A recent review of CFD in drying was carried out by Defraeye [99]. The review mainly focused on CFD application in understanding material behaviour and changing during the drying process. Products such as food, wood and ceramic were considered, and the work didn't study drying process control, design or optimisation. However, Jamaleddine and Ray [107] presented a comprehensive review of CFD applications in drying particularly in context of understanding drying processes on laboratory and industrial scales spray, freeze, and thermal drying techniques. Based on the conclusions, application of CFD in drying offers advantages such as:

[1] Forecasting of local conditions (gas and particles) in the drying chamber.

[2] Useful in comparison of different feed-point layout especially dryers with multiple entry points.

[3] Provides useful data on distribution of particles from feed-point region especially on flash dryers.

[4] Suitability in troubleshooting especially in evaluation of different geometries and operating conditions of the dryers.

One striking fact is that more attentions are paid to the use of CFD in crop dryers which are suitable for the application of smallholders' farmers or community/cooperative drying systems. CFD can be a useful tools to designing of innovative dryers or improving the configuration of the existing dryers. Therefore, some detailed examples of crop drying by using CFD are listed in the rest of this section.

The design and evaluation of a hybrid solar thermal and desiccant infrared drying unit were undertaken by Punlek et al. [108]. Different configurations e.g. shapes and fins of PV air collectors and desiccant bed were investigated using TRNSYS and CFX simulator. Result indicated that finned photovoltaic air collectors and $\mathrm{V}$ shaped desiccant bed provided a uniformed air profile. A good agreement was observed with experimental data used for validation. Furthermore, Lokeswaran and Eswaramoorthy [109] worked on an existing solar greenhouse dryer. Computational fluids' GAMBIT and FLUENT packages were used for the simulation. Fine mesh were used in the region around the trays and flue gases while coarse mesh was adopted on the regions away from the trays. Thus, about 914,905 tetrahedral cells (meshes) were used. Results revealed inhomogeneity of drying air profile within the 
dryer. Thus suggestions were conducted for an improved air distribution.

To overcome the problem associated with spatial non-uniformity of drying air for tray dryer, Amjad et al. [110] investigated a new batch dryer with diagonally airflow inlet channel along the length of the dryer, which was presented in Fig. 11a. Two configurations: straight and diagonal airflow inlet were assessed with FLUENT. The straight flow was modelled with 9,613,901 cells while 9,542,733 cells was adopted for the diagonal airflow, which are based on the channels in Fig. 11b. The outcome of diagonal airflow inlet presented a better air distribution. The configuration was fabricated and experimented with potato cubes, which indicated a uniform moisture content along the 25 drying trays. Similarly, Misha et al. [111] assessed four different configurations of tray dryers and using Navier-Stokes (NS) equations for calculating mass, momentum and energy continuum in the dryer. The best shape was analysed and selected which give a better uniformity of air temperature and velocity. Drying test was conducted with Kenaf Core which was reported to have even moisture content.

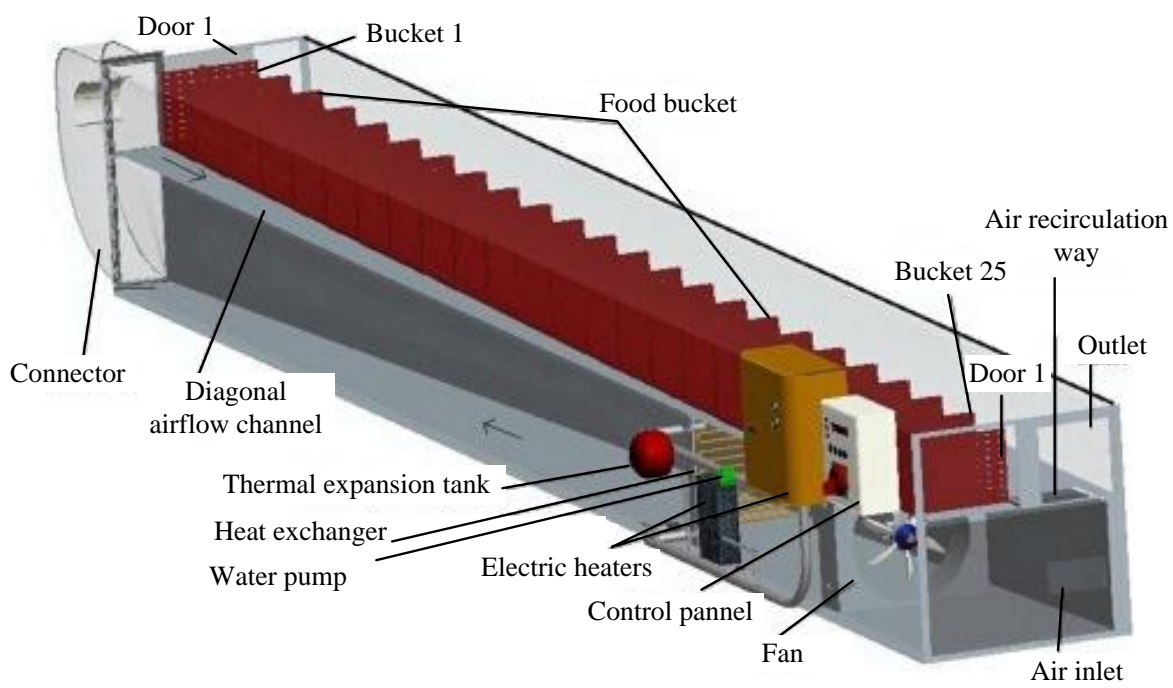

(a)

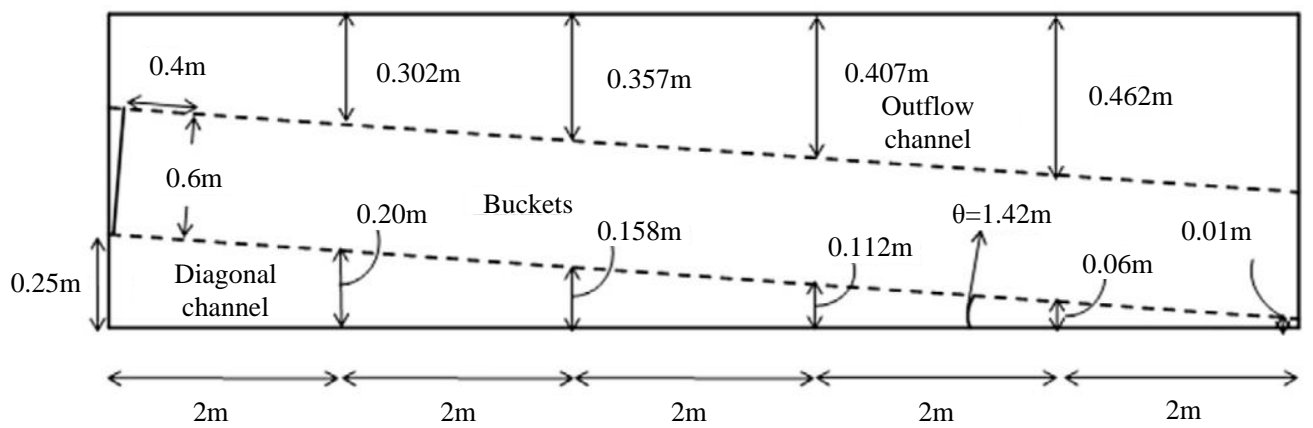

(b)

Fig. 11. Tray dryer with diagonally airflow inlet (a) system schematic; (b) air flow channels [110]. 
The limitation of the existing commercial drying simulation tools only focuses on the phenomenon within drying units without considering heat sources. To overcome this disadvantage, an hybrid software called DryDSim which combined Matlab with SolidWorks was used by Neba and Nono [112] for the design and analysis of a hybrid biomass-solar tunnel cabinet dryer. The concerning model was presented in Fig. 12. The package was experimentally tested with laboratory drying experiments using green pepper The software was able to accurately predict the design and operational parameters of the dryer, temperature dynamics of drying and quantity of biomass briquette required. Importantly, the dryer was able to do cost evaluation such as NPV, internal rate of return and the total annual cost using the following inputs: lifespan, interest rate, product mass and the unit cost per $\mathrm{kg}$ of the dried products.

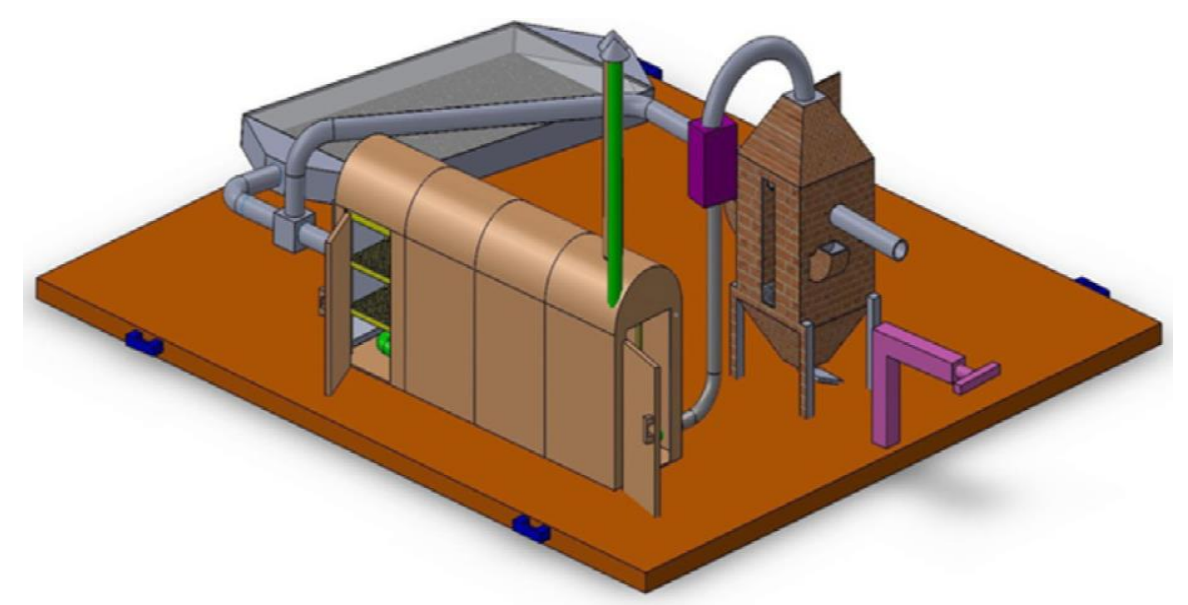

Fig. 12. Model of the solar-biomass hybrid tunnel dryer [112].

In order to have a comprehensive comparison, some selected research studies on application of numerical modelling tools are indicated in Table 6 , which are also related with sustainable food drying. It is demonstrated that a good computational model should integrate heat and mass transfer with other physical processes, e.g. air flow, radiation, etc. Then a more complete model could be established to evaluate product quality together with energy usage and energy efficiency. Sensitivity analysis to the drying process should also be conducted before simulation. Eventually, simulation is better to be validated which is to evaluate the accuracy of established model. For agriculture products, lack of food properties required for modelling is the bottleneck. The properties are almost not included in the software and requires a good summarization in the future.

Table 6. Selected studies on applications of numerical modelling tools used in sustainable drying. 


\begin{tabular}{|c|c|c|c|}
\hline $\begin{array}{l}\text { Modelling approach/ } \\
\text { software used }\end{array}$ & Agro-product & Study criteria/research findings & Ref. \\
\hline $\begin{array}{l}\text { Matlab to solve } \\
\text { Crank-Nicholson } \\
\text { drying model }\end{array}$ & Cocoa beans & $\begin{array}{c}\text { Moisture content is reduced from } 50 \% \text { to } 7 \% \\
\text { within } 7 \text { days; The good system sensitivity is } \\
\text { achieved. }\end{array}$ & [103] \\
\hline $\begin{array}{l}\text { Drying kinetics } \\
\text { modelling with }\end{array}$ & Potato & $\begin{array}{l}\text { Drying optimisation is carried out and page model } \\
\text { allegedly perfectly predicts potato drying. }\end{array}$ & [104] \\
\hline Simprosys & Lignite & $\begin{array}{l}\text { Power generation is increased by } 1.3 \% \text {; A reduced } \\
\text { cost of energy delivery is achieved. }\end{array}$ & [105] \\
\hline $\begin{array}{l}\text { Combustion drying } \\
\text { modelling with } \\
\text { Simprosys }\end{array}$ & - & $\begin{array}{l}\text { The moisture carrying property of air and } \\
\text { combustion gas is pressure dependent. }\end{array}$ & [106] \\
\hline Comsol & Carrot & $\begin{array}{l}\text { Spatial moisture profiles are predicted at all times } \\
\text { using NS 2D model; Simulations results are in } \\
\text { good agreement with experimental data. }\end{array}$ & [113] \\
\hline Comsol & Carrot slice & $\begin{array}{l}\text { A modified Arrhenius-type relationship is used to } \\
\text { for the process temperature variations which is } \\
\text { independent on heat and mass transfer coefficients. }\end{array}$ & [114] \\
\hline Comsol & Potato discs & $\begin{array}{l}\text { A complete set of driving parameters are exploited } \\
\text { for optimization based on geometry and heating } \\
\text { mechanism. }\end{array}$ & [115] \\
\hline CFD & Potato & $\begin{array}{l}\text { Drying time is reduced with ohmic heating as } \\
\text { moisture diffusion in the product is enhanced, } \\
\text { leading to a simultaneous heat and mass transfer. }\end{array}$ & [116] \\
\hline CFD & Apple & $\begin{array}{l}\text { Large-eddy simulation is more accurate than } \\
\text { Reynolds-averaged Navier-Stokes (RANS) } \\
\text { turbulence model but at high computational cost; } \\
\text { Combination of the former with low Renolds } \\
\text { number modelling gives a better accuracy. }\end{array}$ & [117] \\
\hline TRANSYS and CFX & 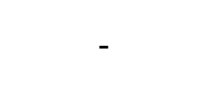 & $\begin{array}{l}\text { Finned PV air collector with V shaped desiccant } \\
\text { bed is able to give a uniformed air distribution. }\end{array}$ & [108] \\
\hline $\begin{array}{l}\text { GAMBIT and } \\
\text { FLUENT }\end{array}$ & $\begin{array}{l}\text { Greenhouse } \\
\text { simulation }\end{array}$ & $\begin{array}{l}\text { Inhomogeneity of air profile within the dryer is } \\
\text { detected. }\end{array}$ & [109] \\
\hline FLUENT & - & $\begin{array}{c}\text { Diagonal air flow gives a better distribution of air } \\
\text { flow. }\end{array}$ & [110] \\
\hline FLUENT & Kenaf Core & $\begin{array}{l}\text { Different configurations is tested and one with } \\
\text { better air profile is selected. } \\
\text { Good agreement between simulation and } \\
\text { experimental results is achieved. }\end{array}$ & [111] \\
\hline FLUENT & Apple & $\begin{array}{l}\text { Vapour diffusion is more dominant than freeze } \\
\text { drying process at temperature below } 0^{\circ} \mathrm{C} \text {. } \\
\text { Diffusional resistance of porous tissue is also } \\
\text { revealed by CFD. }\end{array}$ & [118] \\
\hline FLUENT & $\begin{array}{l}\text { Horticultural } \\
\text { products }\end{array}$ & $\begin{array}{l}\text { RANS is joined with the shear stress transport k- } \omega \\
\text { model for the microscale modelling of horticultural } \\
\text { products. } \\
\text { The model is found to have a good result over a } \\
\text { wide range of Reynolds number }\left(10-3 \times 10^{4}\right) .\end{array}$ & [119] \\
\hline FLUENT & - & $\begin{array}{l}\text { CFD model is reportedly in good agreement with } \\
\text { experimental data and is able to predict the } \\
\text { condensation, temperature and humidity change. }\end{array}$ & [120] \\
\hline Fluent CFD package & Apple slices & $\begin{array}{l}\text { NS 2D model is used; Heat and mass transfer } \\
\text { coefficients have been well predicted. }\end{array}$ & [121] \\
\hline
\end{tabular}

\section{Exergy analysis}

Exergy denotes a function of irreversibility within the system. It describes energy destruction within 
a thermodynamic system and could be perceived as the maximum obtainable useful work of a thermodynamic system when it brings to the equilibrium with its surrounding [122]. Thus exergy analysis gives an indication where thermodynamic improvements are required to make a system as energyefficient as possible. Its evaluation can provide a useful tool in accessing the cost of thermodynamic irreversibility and seek to reduce such loss as much as possible and decrease the environmental impacts of drying process [123, 124]. Generally, the exergy of a drying unit can be expressed as equation 3 [125].

$$
\mathrm{E}=C_{\mathrm{p}, \mathrm{da}}\left[\left(T-T_{\mathrm{a}}\right)-T_{\mathrm{a}} \ln \frac{T}{T_{\mathrm{a}}}\right]
$$

where $C_{\mathrm{p}, \mathrm{da}}, T_{\mathrm{a}}$ and $T$ represent the specific heat capacity of the drying air, ambient and reference temperature, respectively.

Exergy efficiency of drying system has been found to be directly proportional to mass flow rate of the product while it is inversely related with the drying temperature, air mass flow rate and humidity ratio [126, 127]. Increasing the velocity of drying air has little influence on exergy efficiency [128]. A recent comprehensive review of exergy analysis of drying systems was presented by Aghbashlo et al. [123]. Their work was composed of HP, fluidized bed, solar, freeze, and vacuum and flash drying. Nonetheless, our interest in this part mainly relies on the exergy analysis of solar and recovered heat powered convective cabinet dryers since these set of dryers are particularly used by the smallholders farmers in remote areas. Some representative examples are elaborated in terms of hybrid dryer, CHP and PV integrated systems, etc.

Luo et al. [129] worked on a grey relational evaluation of an hybrid cascading technique where the waste water from an existing geothermal plant was proposed to be used for drying of logan fruits and bathing water provision. The new configuration increased system exergy efficiency from $12.76 \%$ to 25.81\%. An assessment of exergetic efficiency of a ground source HP dryer was conducted by Kuzgunkaya and Hepbasli [130]. Exergy efficiency on a product to fuel basis was found between $21.1 \%$ and $15.5 \%$. A process integrated with efficient drying of micro algae was researched by Aziz et al. [131]. In their work, steam produced from micro algae gasification was used for power generation. Heat from the steam was also used for drying microalgae while flue gas from gasification system was utilised in the pond and served as nutrients for microalgae. Exergy recovery within the system reportedly increased exergy efficiency and a coefficient of drying performance could reach 18.5. Besides, Ganjehsarabi et al. [132] used exergy and exergoeconomic evaluation approach to optimise the efficiency of a HP tumbler dryer for drying fabrics. Exergetic efficiency of HP and whole system were 0.07 and $0.11 \%$ which was a 
function of operating temperature and flow rate. Correspondingly, a solar evacuated tube heat pipe for water heating and drying of agricultural purpose was designed and experimentally studied for energy and exergy efficiency by Daghigh and Shafieian [133]. Heat from evacuated tube was recovered into a water storage tank. It was subsequently used for domestic purpose and heating of drying air. Exergy efficiency of the system is dependent on time and ambient temperature. The highest exergy destruction was noticed during the time, which indicated the highest solar intensity of the day and high ambient temperature.

A multigenerational biomass fuelled CHP system was investigated for optimizing exergy and energy efficiency which was composed of electricity generation with heat recovery for district heating, domestic hot water, organic Rankine cycle (ORC), wood steaming and pine wood drying units [134]. Exergy and energy efficiency of the system was found to be $60 \%$ and $25 \%$, respectively when compared with $11 \%$ and $13 \%$ noted for single power generation system. Moreover, exhaust heat recovery for district heating and drying of wood was demonstrated to have more influence on energy efficiency than exergy efficiency while power generation and heat recovery for drying were noted to have the highest exergy efficiency. Geothermal heat recovery cabinet drying of olive leaves was evaluated by Helvacı and Akkurt [42] from Balcova-Narlidere Geothermal Field in Turkey. Drying was conducted with and without drying air exhaust recirculation. Expectedly, energy utilization ratio was 7.96 and 50.36 in terms of the former and later system while exergy destruction at the outlet of recirculated system was reduced from 0.1013 $\mathrm{kW}$ to $0.08104 \mathrm{~kW}$. Likewise, Coskun et al. carried out exergy and energy assessment of a wood chips drum dryer powered with waste heat from a co-generational system [135]. Exergy and energy efficiency were found to reach $34.07 \%$ and $4.39 \%$, respectively. However, it was suggested that economiser was incorporated with waste heat recovery for district heating. Analysis indicated that energy and exergy efficiency were increased to $93.15 \%$ and $43.08 \%$, respectively. Similarly, Sarker et al. analysed exergy of an industrial fluidised bed dryer for paddy drying [136]. The study demonstrated exergy used for drying was from $31.18 \%$ to $37.01 \%$. Hence, thermal insulation and waste heat recovery were suggested but subject to economic evaluation. Besides, a simple heat exchanger was used by Ghasemkhani et al. [137] to improve the exergetic efficiency of a rotary drum dryer which was applied for drying of apple slices. Heat was recovered from the dryer's exhaust and then used to preheat ambient air before entering the main heater of the dryer. This configuration improved exergetic efficiency from $23 \%$ to $96.1 \%$ and had not negative impact on the quality of dried apple slices especially considering shrinkage and rehydration ratio. 
Tiwari et al. presented performance analysis of a PV/T greenhouse dryer [138]. Different climatic and operational conditions were investigated. Numerical modelling was developed using crop, greenhouse and solar unit temperatures as input to evaluate system thermal efficiency. A good agreement was found between the analysed theoretical and experimental energy and exergy of the system with the correlation coefficient of 0.98 . Boulemtafes and Benzaoui assessed exergetic efficiency of a discontinuous solar dryer for mint drying [139]. A linear relation was observed between energy consumption and exergy destruction. It was higher in the second day which could be attributed to the predominance of falling drying rate. An analytical expression for the exergy efficiency in greenhouse drying of fish was researched by Tiwari et al. under the conditions of natural and forced convection [140]. As expected, exergetic efficiency was lower under forced convection than that under natural convection but drying rate of forced convection proved to be faster due to a better moisture removal by the fan.

Drying of olive oil waste water from $3.153 \mathrm{~g}_{\text {water }} \cdot \mathrm{g}_{\text {dry matter }}{ }^{-1}$ to $1.000 \mathrm{~g}_{\text {wate }} \cdot \mathrm{g}_{\text {dry matter }}{ }^{-1}$ in a natural convective solar cabinet dryer was investigated by Celma and Cuadros [141]. Drying was conducted for two days, and exergy efficiency was found to fluctuate between $53.4 \%$ to $100 \%$ and $34.4 \%$ to $100 \%$ in the first and second day. This is because the second day falls on the falling rate during the drying period and the available energy could not be fully utilised. Besides, using first and second laws of thermodynamics, forced solar drying of mulberry was assessed by Akbulut and Dumus [142]. Product mass flow rate, drying air velocity and drying time were used as variable parameters. Exergy destruction was found to be reduced when product mass flow rate was increased. Then an increased exergy efficiency was obtained.

Chowdhury et al. investigated exergy efficiency of a solar tunnel dryer for jackfruit drying [143]. It had been found that exergy efficiency was reduced with the increase of solar radiation, which varied between $32.34 \%$ and $65.30 \%$ in terms of a corresponding increase in solar radiation from $100 \mathrm{~W} \cdot \mathrm{m}^{-2}$ to $600 \mathrm{~W} \cdot \mathrm{m}^{-2}$. Yahya et al. [144] also researched exergy analysis of an integrated fluidized bed dryer for paddy drying. The dryer was composed of solar collector and biomass furnace for drying air heating. Air was first heated with solar collector and then raised to the drying temperature with biomass furnace. The dryer was able to reduce the moisture content of paddy rice from $20 \%$ to $14 \%$ during 13.3 minutes to 21.3 minutes while exergy efficiency of $47.6 \%$ and $49.5 \%$ were reported at drying temperature between $61^{\circ} \mathrm{C}$ and $78^{\circ} \mathrm{C}$, respectively. However, exergy loss was observed to reduce with drying time. It was suggested that bulk of drying of paddy rice took place in the falling rate period. 
Some selected studies on exergy analysis of agro-product drying are presented in Table 7. It is worth noting that most of the research studies focus on heat optimisation of drying systems to reduce exergy destruction. Heat recovery, air recirculation and insulation are predominantly suggested techniques of increasing exergy efficiency. However, more works are required to be done in terms of the economics of heat recovery and its effect on the quality of dried products. In this regards, the use of local or composite materials for dryer construction could be explored. For instance, combination of red bricks with poultry feathers as insulation materials could bring both economic and thermodynamics advantages in the construction of large community-based cabinet dryers for the remote areas of developing countries.

Table 7. Selected publications on exergy analysis of agro-product drying.

\begin{tabular}{|c|c|c|c|}
\hline Research Approach. & Agro-product & Remarks & Ref. \\
\hline $\begin{array}{l}\text { Exergy analysis } \\
\text { using grey } \\
\text { relational } \\
\text { evaluation }\end{array}$ & Logan fruit & $\begin{array}{l}\text { Exergy efficiency is increased from } 12.76 \% \text { to } \\
25.81 \% \text {. }\end{array}$ & [69] \\
\hline Ground source HP & Laurel leaves & $\begin{array}{l}\text { Exergy effectiveness on a product to fuel basis is } \\
\text { reportedly between } 21.1 \text { and } 15.5 \% \text {. } \\
\text { Condenser unit accounts for the greatest exergy } \\
\text { destruction. }\end{array}$ & [130] \\
\hline $\begin{array}{l}\text { Heat recovery from } \\
\text { micro algae } \\
\text { gasification }\end{array}$ & Micro algae & $\begin{array}{l}\text { An increased exergy efficiency and an } 18.5 \\
\text { coefficient of drying performance are achieved. }\end{array}$ & [131] \\
\hline $\begin{array}{l}\text { Multigenerational } \\
\text { biomass fuel CHP }\end{array}$ & Pine drying & Exergy efficiency is increased from $11 \%$ to $60 \%$. & [134] \\
\hline $\begin{array}{l}\text { Exergy evaluation } \\
\text { of a discontinuous } \\
\text { solar dryer }\end{array}$ & Mint leaves & $\begin{array}{l}\text { A linear relation is observed between energy } \\
\text { consumption and exergy destruction and is } \\
\text { reportedly higher in the second day due to the } \\
\text { prevalence of falling drying rate. }\end{array}$ & [139] \\
\hline $\begin{array}{l}\text { Geothermal exhaust } \\
\text { heat recovery } \\
\text { cabinet drying }\end{array}$ & Olive leaves & $\begin{array}{l}\text { Energy utilization ratio is increased from } 7.96 \text { to } \\
\qquad 50.36 .\end{array}$ & {$[42]$} \\
\hline $\begin{array}{l}\text { Exergy efficiency in } \\
\text { greenhouse drying }\end{array}$ & Fish & $\begin{array}{l}\text { Exergy efficiency is lower in forced convective } \\
\text { drying than natural drying but drying rate is faster in } \\
\text { the former. }\end{array}$ & [140] \\
\hline $\begin{array}{l}\text { Heat recovery from } \\
\text { a rotary drum dryer }\end{array}$ & Apple slices & $\begin{array}{l}\text { Exergetic efficiency increased from } 23 \% \text { to } 96.1 \% \\
\text { and doesn't affect the quality of dried apple slices. }\end{array}$ & [137] \\
\hline $\begin{array}{l}\text { Fluidised bed with } \\
\text { solar and biomass } \\
\text { furnace }\end{array}$ & Rice paddy & Exergy loss is reduced with drying time. & [144] \\
\hline $\begin{array}{l}\text { Exergy analyses of } \\
\text { a forced convection } \\
\text { solar tunnel dryer }\end{array}$ & $\begin{array}{l}\text { Chilli pepper } \\
\text { and ginger }\end{array}$ & $\begin{array}{l}\text { Exegetic efficiency increases with advancing in } \\
\text { drying time, and high exergetic efficiency is } \\
\text { obtained in the last few hours of the drying. }\end{array}$ & [145] \\
\hline $\begin{array}{l}\text { Energy and exergy } \\
\text { analysis of HP } \\
\text { dryers. }\end{array}$ & Grated carrot & $\begin{array}{l}\text { A successful and efficient combination of HP and } \\
\text { infrared heater is obtained in food drying. }\end{array}$ & [146] \\
\hline $\begin{array}{l}\text { Exergetic analysis } \\
\text { of deep-bed drying }\end{array}$ & Rough rice & $\begin{array}{l}\text { Higher drying air temperatures result in higher } \\
\text { exergy efficiency. The process is highly capable of } \\
\text { ameliorating exergy performance improvement. }\end{array}$ & [147] \\
\hline
\end{tabular}




\section{Economic evaluation of the drying units}

The design of sustainable drying systems for rural farmers should be efficient and reliable. It is also required to be simple and affordable especially when compared with conventional fossil fuel or electricity driven dryers [148]. Besides, initial cost should be affordable, and the cost of maintenance must be inexpensive and reasonably consistent. This is because if initial cost is too high, such equipment may be unaffordable for poor farmers. At the same time, it is difficult to maintain a dryer for processing agricultural products, which will be too expensive to compete at the local market. Thus, farmers are only disposed to employ dryers which provide profitable returns on investment and maintenance costs of the drying operation [149]. For instance, butane fuelled Atesta dryer is mostly used by mangoes farmers in Burkina Faso. Despite efforts by the local and foreign donors together with government on initial cost of the dryer, above $50 \%$ of the country mangoes still got wasted every year. This is largely due to the availability and fluctuating cost of butane which results in about $€ 0.07 \cdot \mathrm{kg}^{-1}$ of evaporated water when compared with solar dried products at $€ 0.01 \cdot \mathrm{kg}^{-1}$ of evaporated water [150]. In spite of improved quality, Atesta processed mangoes are not competitive in the local market.

To reduce the aforementioned challenges of Atesta dryer, Nonclercq at al. [151] studied a similar configuration as illustrated in Fig. 13. It was an integrated sun-gas powered system which operated on solar collectors during the day and gas powered after sunset or on bad weather. Heat was transferred from a $17.3 \mathrm{~m}^{2}$ solar collector to $112 \mathrm{~L}$ water in the water tank which stabilises the drying temperature as well as provides heat storage for subsequent use after sunset. Two small pumps were used: one was for fluid transfer through solar panels and the other was for pumping fluid through heat exchanger of the drying chamber. It ensured that $97 \%$ of the required energy was supplied by solar system and the unit dried 40 $\mathrm{kg}$ of agricultural product per batch. Economically, the specific drying cost per kilogram was reported to be 15 Central African Francs (CFA) in comparison with 22 CFA for the butane driven Atesta dryer. However, pumps of the system driven by electricity indicated that the system either depended on unreliable national grid (where available) or generator sets. Similarly, a hybrid solar-biomass fish tray dryer was designed and evaluated by Hamdani et al. [152]. A $260 \mathrm{~cm}$ by $80 \mathrm{~cm}$ dryer was driven by solar energy between 9 am and $4 \mathrm{pm}$ while the drying temperature of $40-50^{\circ} \mathrm{C}$ was maintained thereafter through a biomass fuelled crossflow heat exchanger. With 300 days operational period per year, the 100 $\mathrm{kg}$ capacity dryer had an $18.61 \%$ internal rate of return, positive NPV and able to break even in 2.6 years. 
An economic analysis to redesign a $180 \mathrm{~kg}$ capacity steam driven cashew nut dryer was assessed by Dhanushkodi et al. [153]. There configurations were proposed for the steam generator boiler by using solar, biomass and hybrid solar-biomass. Results of the analysis indicated that payback periods were 1.58 years, 1.32 years and 1.99 years for solar, biomass and hybrid modes, respectively. However, the cost benefit appraisal was 5.23 for solar, 4.15 for biomass and 3.32 for the hybrid system. Hence, hybrid mode was recommended. Similary, El Hage et al. [27] presented their work on the economic analysis of replacing a $15 \mathrm{~kW}$ capacity cabinet dryer currently powered with electric heaters. The operating temperature for specific crop varied from $50^{\circ} \mathrm{C}$ to $140^{\circ} \mathrm{C}$. The dryer was examined for the drying of carrots, corn, mushrooms, potatoes, apples, bananas, cherries and peaches. The results indicated that the viability of the system was strongly influenced by the price, quantity and type of crop dried. Saved money by adopting solar drying varied from $5460 \$ \cdot \mathrm{month}^{-1}$ to $130 \$ \cdot \mathrm{month}^{-1}$ for cherries and carrot while the corresponding payback period was equally reduced from 62 months for carrot and 1.5 months for cherries.

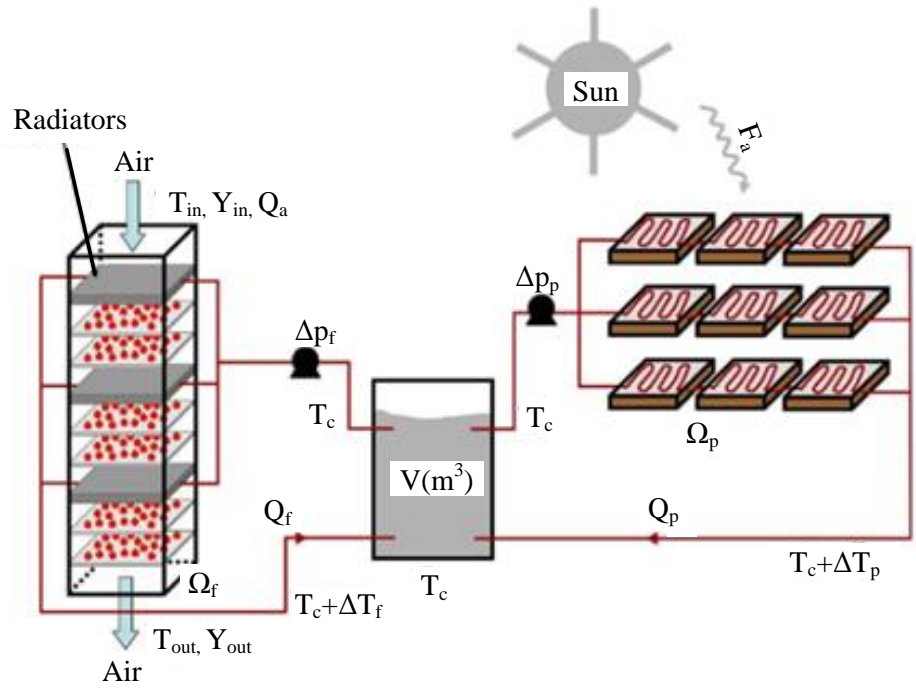

Fig. 13. Mixed sun-gas driven tray dryer [151].

An innovative multi-shelf solar dryer with cooker was studied by Singh and Sethi [154]. The parallelepiped shape configurations was suitable for 280 days in a year and the system had a payback period of 5 years and 5 months. Moreover, the combination of cooking with drying was proved to present a huge savings for rural households. ELkhadraoui et al. [155] examined a mixed mode solar greenhouse dryer using pepper and grape. Solar PV system provided electricity to drive fan for forced air convection in the greenhouse dryer and the configuration reduced the drying time of red pepper and grape by $7 \mathrm{~h}$ 
and $17 \mathrm{~h}$, respectively while the dryer's payback period was 1.6 years. Besides, a double-pass solar collector dryer equipped with fin absorber and additional heater was studied for seaweed drying by Fudholi et al. [156]. Economic analysis of the system had a 2.33 years payback period for marine products drying.

Nayak et al. [157] considered a PV panel-PV/T integrated forced convection solar dryer which was displayed in Fig. 14. PV/T unit supplied heat input for the drying air and a direct current fan was powered with PV panels. Economic evaluation of the dryer with cauliflower in Haryana India weather indicated a 5.6 years payback period with 352 Indian rupees as the cost benefit.

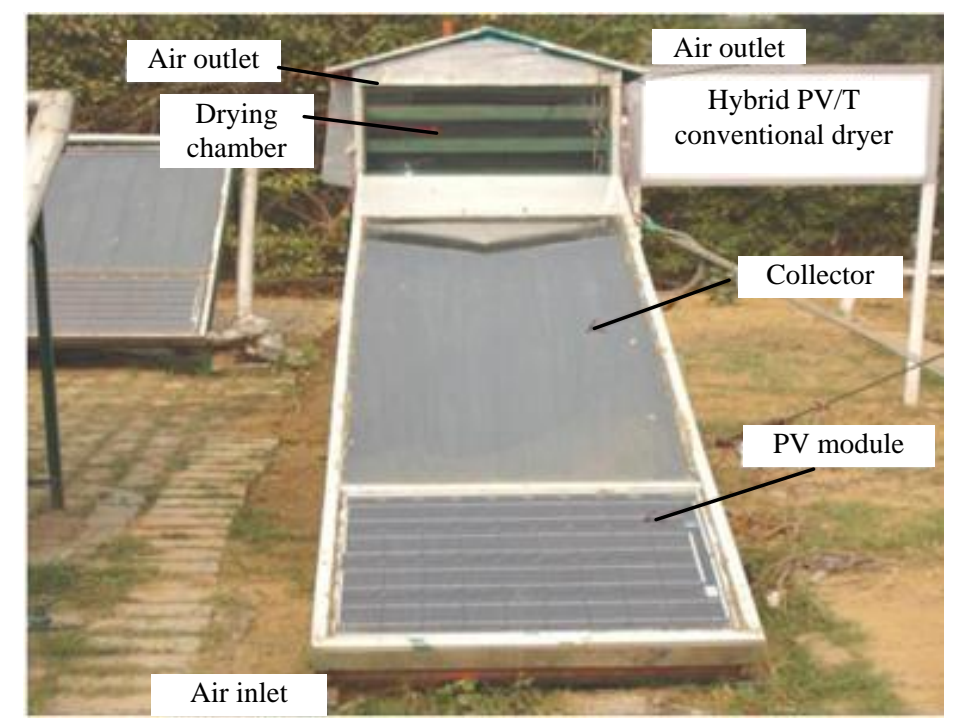

Fig. 14. Solar PV-PV/T integrated cabinet dryer [157].

Chauhan et al. [158] fabricated and studied a forced convection greenhouse dryer which was integrated with solar collector and adjustable speed exhaust fan. At an air flowrate of $0.0551 \mathrm{~kg} \cdot \mathrm{s}^{-1}$, the studied dryer reduced moisture content of bitter gourd flakes from $96.8 \%$ to $12.2 \%$ in 17 hours. The dryer with 35 years life span payed back in 1.5 years. Similarly, Nabnean et al. [159] worked on a thermal storage assisted solar dryer as demonstrated in Fig. 15 for drying of osmotically dehydrated tomato cherries. The dryer was made up of a $300 \mathrm{~L}$ water storage tank, solar collector, heat exchanger and drying cabinet, which was dependent on the solar radiation, relative humidity and temperature of drying air. It had solar collector efficiency and payback period of $21 \%-69 \%$ and 1.37 years, respectively. However, except for technical or economic evaluations of the systems, other studies may be required on the most efficient way of altering negative socio-cultural perceptions of the farmers against some renewable 
energy technologies. For instance, while anaerobic digestion provides an excellent way of energy recovery from organic waste which can be subsequently used as drying fuel, some cultures have strong objections regards by utilising animal and human waste as feedstocks [160]. Some still erroneously perceived whatever that comes from waste as the dirty [161] so that people who used such materials was considered to be the bottom of the social ladder [162]. Some recent works on the economic evaluation of sustainable drying are presented in Table 8 .

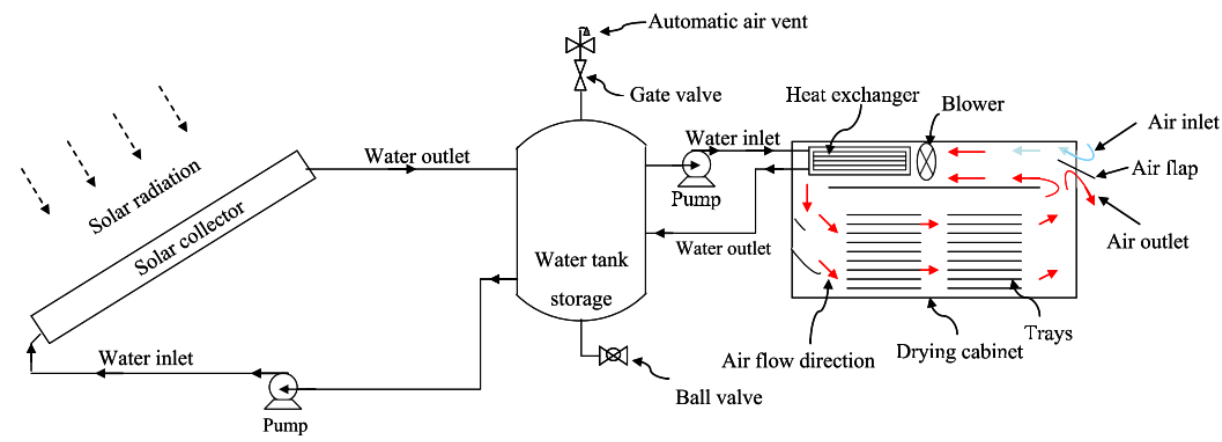

(a)

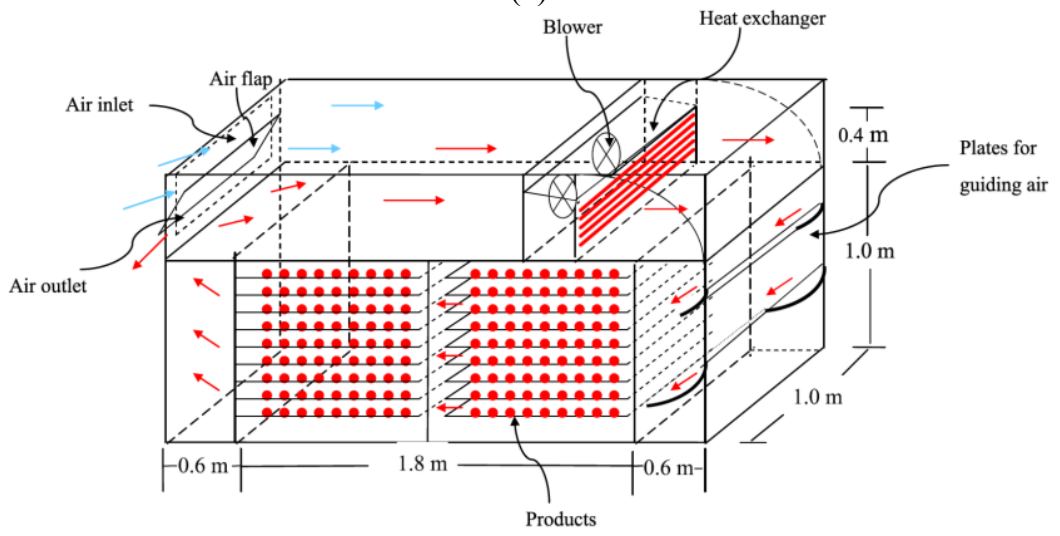

(b)

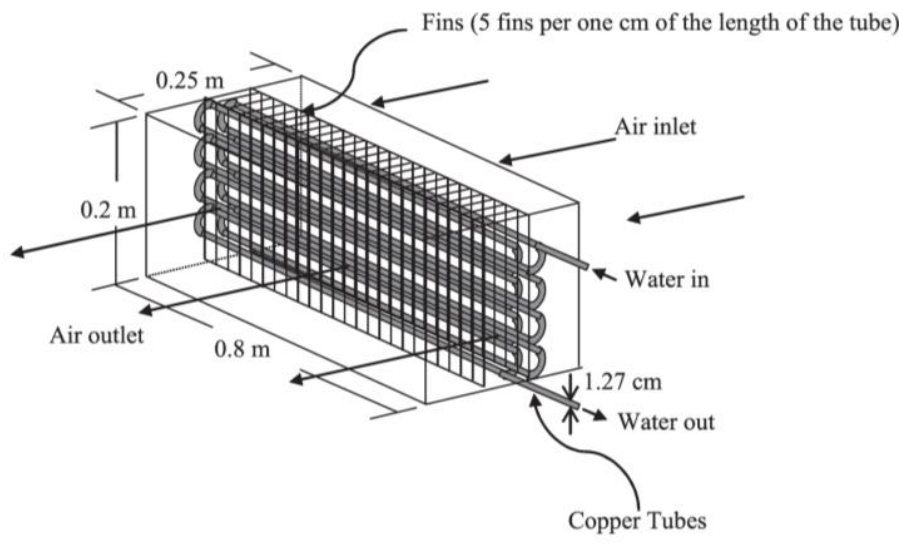

(c)

Fig. 15. Schematic of thermal storage assisted solar dryer (a) the system; (b) the drying cabinet; (c) heat exchanger [159]. 
Table 8. Selected works on economic analysis of renewable energy powered dryers.

\begin{tabular}{|c|c|c|c|}
\hline $\begin{array}{c}\text { Modelling approach/software } \\
\text { used }\end{array}$ & Agro-product & Study criterial/research findings & Ref. \\
\hline $\begin{array}{c}\text { Experimental comparison } \\
\text { between Butane fuelled Atesta } \\
\text { dryer and solar dryer }\end{array}$ & Mango & $\begin{array}{l}€ 0.01 \cdot \mathrm{kg}^{-1} \text { of evaporated water is for } \\
\text { solar dried mango against } € 0.07 \cdot \mathrm{kg}^{-1} \\
\text { evaporated water for Atesta dryer. }\end{array}$ & [149] \\
\hline $\begin{array}{l}\text { Experimental testing mixed } \\
\text { sun-gas powered system with } \\
\text { water storage compared to } \\
\text { Atesta dryer }\end{array}$ & $\begin{array}{l}\text { Tomato and } \\
\text { mango }\end{array}$ & $\begin{array}{l}\text { Drying cost } 15 \mathrm{CFA} \cdot \mathrm{kg}^{-1} \text { is for the } \\
\text { mixed sun-gas system; Drying cost is } \\
22 \mathrm{CFA} \cdot \mathrm{kg}^{-1} \text { for Atesta. }\end{array}$ & {$[151]$} \\
\hline Hybrid solar biomass dryer & Fish & $\begin{array}{l}\text { Payback period is } 2.6 \text { years for hybrid } \\
\text { system. }\end{array}$ & {$[152]$} \\
\hline $\begin{array}{l}\text { Mixed solar-biomass dryer } \\
\text { tested at different modes }\end{array}$ & $\begin{array}{l}\text { Agricultural } \\
\text { product }\end{array}$ & $\begin{array}{l}1.58 \text { and } 1.32 \text { years payback period is } \\
\text { for solar and biomass only; } 1.99 \text { years } \\
\text { payback period is for hybrid. }\end{array}$ & {$[153]$} \\
\hline $\begin{array}{l}\text { A } 15 \mathrm{~kW} \text { electric heater dryer } \\
\text { replaced with a similar solar } \\
\text { dryer. }\end{array}$ & $\begin{array}{c}\text { Carrots, corn, } \\
\text { mushrooms, } \\
\text { potatoes, apples, } \\
\text { bananas, } \\
\text { cherries and } \\
\text { peaches. }\end{array}$ & $\begin{array}{l}\text { The price, quantity and type of crop } \\
\text { dried determines the system's viability; } \\
\text { Depending on the crop processed, } \\
\text { payback period varies from } 62 \text { months } \\
\text { for carrot and } 1.5 \text { months for cherries. }\end{array}$ & {$[27]$} \\
\hline $\begin{array}{l}\text { A multi-shelf solar dryer cum } \\
\text { cooker }\end{array}$ & $\begin{array}{l}\text { Agricultural } \\
\text { product }\end{array}$ & $\begin{array}{c}\text { Payback period is } 5 \mathrm{y} \\
\text { months. }\end{array}$ & {$[154]$} \\
\hline $\begin{array}{l}\text { Mixed mode solar greenhouse } \\
\text { dryer }\end{array}$ & $\begin{array}{l}\text { Pepper and } \\
\text { grape }\end{array}$ & Payback period of 1.6 years is reported. & {$[155]$} \\
\hline $\begin{array}{l}\text { Double-pass solar collector } \\
\text { dryer equipped with fin } \\
\text { absorber and additional heater }\end{array}$ & Seaweed & $\begin{array}{c}\text { Payback period of } 2.33 \text { years is } \\
\text { reported. }\end{array}$ & {$[156]$} \\
\hline Solar PV\&PV/T dryer & Caulifl & $\begin{array}{c}\text { Payback period of } 5.6 \text { years is } \\
\text { recorded. }\end{array}$ & {$[157]$} \\
\hline $\begin{array}{l}\text { Forced convection greenhouse } \\
\text { dryer }\end{array}$ & $\begin{array}{l}\text { Bitter gourd } \\
\text { flakes }\end{array}$ & $\begin{array}{c}\text { Payback period of } 1.5 \text { years is } \\
\text { evaluated. }\end{array}$ & {$[158]$} \\
\hline
\end{tabular}

\section{Life cycle assessment study on sustainable drying of agricultural products.}

Life cycle assessment (LCA) is an analytical tool developed to assess the environmental burden of products from cradle to grave, which is often expressed in terms of greenhouse gas (GHG) emissions [163]. It is widely believed to increase understanding on the environmental impacts of various products by identifying energy, materials consumed as well as environmental emission during the life cycle of a product, processes or services. Hence, a LCA study of agricultural drying systems could provide insights into what, how and which parts or operational schedule of drying has the highest environmental burden and where environmental performance improvement would be necessary. LCA studies of renewable energy powered dryers are particularly scanty and some examples are illustrated as follows.

A typical LCA study on drying of Radiata pine by Hague et al. [164] indicated that the highest environmental burden of $74 \%-94 \%$ was associated with electricity used for forced convection while 
thermal energy accounted for $7 \%-26 \%$ of GHG emission which depended on the operational schedule. Moreover, the impact of loading, offloading and dryer construction were insignificant. Similarly, Bowser et al. [165] studied carbon emission of a cabinet tray dryer for Cilantro. The dryer was operated under three different modes: without waste heat recovery (WHR), with WHR as well as with WHR and exhaust recirculation. The result indicated a $\mathrm{CO}_{2}$ emission of 20.0,13.1, and 18.0 tonnes for the above mentioned modes, respectively. Thus WHR reduced $\mathrm{CO}_{2}$ emission by $35 \%$. An increased $\mathrm{CO}_{2}$ emission in the third scenario could be attributed to the power consumption of pump used for recirculation. Besides, recirculation increased retention time which could also had an effect on the overall energy consumption. Besides, Prakash and Kumar [166] investigated a solar greenhouse dryer for tomato flakes and the result suggested a net $\mathrm{CO}_{2}$ emission of 38.06 tonnes compared to 613.48 tonnes of $\mathrm{CO}_{2}$ that would have been produced if the dryer was powered with electricity produced from coal.

\section{Conclusions}

Convectional open solar drying has some drawbacks in terms of quality, capacity, accuracy and process efficiency. Fossil fuelled dependent drying systems are not only uneconomical but also becoming unattractive to world. Therefore, applications of sustainable drying methods are optimal alternative methods to overcome the bottleneck of traditional drying systems whilst decarbonising food drying processes. In this regard, sustainable energy for drying agriculture products will play a significant role to reduce post-harvest losses especially in remote areas where the losses are enormous.

Attempt has been made to review the recent works on sustainable drying of agricultural products especially considering heat recovery, modelling with CFD as well as first and second laws of thermodynamics evaluation. Most of these works seem technically feasible, but affordability and reliability in context of poor rural dwellers remains to be challenging. E.g. availability and affordability of hybrid dryers incorporating LPG or electric heaters could be problematic within isolated communities. Comparably, hybrid solar-biomass system is promising which provides a good operational control maintained. The reasons are illustrated as follows: (1) it reduces the effect of solar intermittency; (2) biomass is readily available in local area; (3) biomass fuelwood is currently the predominant source of heating; (4) solar-biomass drying units are economically superior to others. However, its operational controls and optimisation need be further simulated and validated to ensure its suitability to the drying of different agricultural products. A common limitation of the existing commercial drying modelling and 
simulation tools is restrictions to the phenomena happening in the dryer without considering conditions of energy sources. Therefore, integration of these elements could provide a valuable tool to achieving both qualitative and quantitative sustainable drying.

Deployment of CHP and tri-generation system to remote areas is another prospective approach, which simultaneously provides electricity, heat recovery for sustainable drying and cold storage of agricultural products. The potential of tri-generation in agrarian communities lies on its ability to provide clean energy and reduce post-harvest loss, which could also ensure food security. However, application of exergy analysis is scarce in context of combined power, drying and cooling system or waste heat recovery for drying. Future research studies should focus on matching the economy and exergy effectiveness of drying systems, which could be more insightful in real applications. Although hybrid solar-biomass system is easy to implement in rural areas, deployment of biomass powered CHP systems might be a better solution to post-harvest wastes. But the large scale application requires a special policy and commitment from the government.

Economic analysis of sustainable drying has payback period between 1-6 years. However, this is largely influenced by operational conditions, size of the dryer and agricultural products. Notwithstanding the favourable payback period, deployment of these dryers has been quite slow due to high initial costs or wrong perceptions on part of farmers. Combination of these dryers with cooking can be further explored while cooperative or community central drying units can be adopted to reduce burden of high initial costs on parts of smallholders' farmers. Moreover, altering social perception to embrace some renewable energy technologies may be quite necessary especially in the global south.

Eventually, performance comparison based on the above literatures is summarized in Table 9. It presents an overview of performances among different sustainable energy drying technologies by using single and solar hybrid heat sources, which could give the reader a general understanding in agricultural drying field.

Table 9. Performance comparison by using different drying energy sources.

\begin{tabular}{|c|c|c|c|c|}
\hline \multicolumn{2}{|c|}{ Heat source (s) } & $\begin{array}{c}\text { Thermal } \\
\text { efficiency }(\%)\end{array}$ & $\begin{array}{c}\text { Time savings } \\
(\%)\end{array}$ & $\begin{array}{l}\text { Payback period } \\
\text { (year) }\end{array}$ \\
\hline Solar & & $15-28$ & $28-32 *$ & $0.4-2$ \\
\hline Biomass & & $31.07-43.08$ & $10-16$ & $<5$ \\
\hline CHP & & $18-75.25$ & $50-70$ & $1.8-14.3$ \\
\hline Geothermal & & $20.96-50.36$ & $45-65$ & $1.85-6$ \\
\hline \multirow{2}{*}{ Solar hybrid } & Solar + fossil & $3.17-86$ & $18-25$ & $<5$ \\
\hline & Solar + Electricity & $18-45$ & $24-31.2$ & $<3$ \\
\hline
\end{tabular}




\begin{tabular}{cccc}
\hline Solar + Biomass & $6.6-12.9$ & $44-56.5$ & $2-3$ \\
Solar + heat storage & $12-69.2$ & $<30$ & $1.37-2.7$ \\
Solar + P/VT & $25-70$ & $30-45$ & $3-7$ \\
\hline
\end{tabular}

*Reference drying time against which others are evaluated.

Acknowledgements: This research was supported by the Nigerian Petroleum Technology Development Fund, National Natural Science Foundation of China under contract number (51606118), and CCSInSupply project (EP/N024567/1) funded by Engineering and Physical Science Research Council of the UK.

\section{References}

[1] Anderson J-O, Westerlund L. Improved energy efficiency in sawmill drying system. Applied Energy. 2014;113:891-901.

[2] Babu AK, Kumaresan G, Raj VAA, Velraj R. Review of leaf drying: Mechanism and influencing parameters, drying methods, nutrient preservation, and mathematical models. Renewable and Sustainable Energy Reviews. 2018;90:536-56.

[3] Gungor A, Erbay Z, Hepbasli A. Exergetic analysis and evaluation of a new application of gas engine heat pumps (GEHPs) for food drying processes. Applied Energy. 2011;88(3):882-91.

[4] Kagande L, Musoni S, Madzore J. Design and performance evaluation of solar tunnel dryer for tomato fruit drying in Zimbabwe. IOSR Journal of Engineering. 2012;2(12):1-7.

[5] Rathore NS, Panwar NL. Experimental studies on hemi cylindrical walk-in type solar tunnel dryer for grape drying. Applied Energy. 2010;87(8):2764-7.

[6] Singh PL. Silk cocoon drying in forced convection type solar dryer. Applied Energy. $2011 ; 88(5): 1720-6$.

[7] Sharma A, Chen CR, Vu Lan N. Solar-energy drying systems: A review. Renewable and Sustainable Energy Reviews. 2009;13(6-7):1185-210. 
[8] Chua KJ, Chou SK. Low-cost drying methods for developing countries. Trends in Food Science \& Technology. 2003;14(12):519-28.

[9] Walsh MJ, Gerber Van Doren L, Shete N, Prakash A, Salim U. Financial tradeoffs of energy and food uses of algal biomass under stochastic conditions. Applied Energy. 2018;210:591-603.

[10] Fayose F, Huan Z. Heat pump drying of fruits and vegetables: Principles and potentials for SubSaharan Africa. International Journal of Food Science. 2016:1-8.

[11] Sims R, Energy-smart Food for People and Climate. Food and Agriculture Organisation of the United Nations. 2011. (Issue paper)

[12] Chen S-T, Kuo H-I, Chen C-C. Modeling the relationship between the oil price and global food prices. Applied Energy. 2010;87(8):2517-25.

[13] Pantaleo AM, Fordham J, Oyewunmi OA, De Palma P, Markides CN. Integrating cogeneration and intermittent waste-heat recovery in food processing: Microturbines vs. ORC systems in the coffee roasting industry. Applied Energy. 2018;225:782-96.

[14] Jenniches S. Assessing the regional economic impacts of renewable energy sources - A literature review. Renewable and Sustainable Energy Reviews. 2018;93:35-51.

[15] Lim CH, Lam HL. Biomass supply chain optimisation via novel Biomass Element Life Cycle Analysis (BELCA). Applied Energy. 2016;161:733-45.

[16] Jiang L, Lu HT, Wang LW, Gao P, Zhu FQ, Wang RZ, Roskilly AP. Investigation on a small-scale pumpless Organic Rankine Cycle (ORC) system driven by the low temperature heat source. Applied Energy. 2017;195:478-86.

[17] Demirbaş A. Global renewable energy resources. Energy Sources, Part A: Recovery, Utilization and Environmental Effects. 2006;28(8):779-92. 
[18] Karekezi S, Kithyoma W. Renewable energy strategies for rural Africa: is a PV-led renewable energy strategy the right approach for providing modern energy to the rural poor of sub-Saharan Africa? Energy Policy. 2002;30(11):1071-86.

[19] Jeswani HK, Burkinshaw R, Azapagic A. Environmental sustainability issues in the food-energywater nexus: Breakfast cereals and snacks. Sustainable Production and Consumption. 2015;2:17-28.

[20] Poggi F, Firmino A, Amado M. Planning renewable energy in rural areas: Impacts on occupation and land use. Energy. 2018;155:630-40.

[21] Kemp IC. Fundamentals of energy analysis of dryers. Modern Drying Technology: Wiley; 2012.

[22] Amer BMA, Gottschalk K, Hossain MA. Integrated hybrid solar drying system and its drying kinetics of chamomile. Renewable Energy. 2018;121:539-47.

[23] Li H, Campana PE, Tan Y, Yan J. Feasibility study about using a stand-alone wind power driven heat pump for space heating. Applied Energy. 2018;228:1486-98.

[24] Prakash O, Laguri V, Pandey A, Kumar A, Kumar A. Review on various modelling techniques for the solar dryers. Renewable and Sustainable Energy Reviews. 2016;62:396-417.

[25] VijayaVenkataRaman S, Iniyan S, Goic R. A review of solar drying technologies. Renewable and Sustainable Energy Reviews. 2012;16(5):2652-70.

[26] Patil R, Gawande R. A review on solar tunnel greenhouse drying system. Renewable and Sustainable Energy Reviews. 2016;56:196-214.

[27] El Hage H, Herez A, Ramadan M, Bazzi H, Khaled M. An investigation on solar drying: A review with economic and environmental assessment. Energy. 2018;157:815-29.

[28] Bal LM, Satya S, Naik SN. Solar dryer with thermal energy storage systems for drying agricultural food products: A review. Renewable and Sustainable Energy Reviews. 2010;14(8):2298-314. 
[29] Shalaby SM, Bek MA, El-Sebaii AA. Solar dryers with PCM as energy storage medium: A review. Renewable and Sustainable Energy Reviews. 2014;33:110-6.

[30] Das S, Das T, Srinivasa Rao P, Jain RK. Development of an air recirculating tray dryer for high moisture biological materials. Journal of Food Engineering. 2001;50(4):223-7.

[31] Lewicki PP. Design of hot air drying for better foods. Trends in Food Science \& Technology. 2006;17(4):153-63.

[32] Earle RL. Unit Operations in Food Processing New Zealand Institute of Food Science and Technology. 2004.

[33] Lowder SK, Skoet J, Raney T. The number, size, and distribution of farms, smallholder farms, and family farms worldwide. World Development. 2016;87:16-29.

[34] Colak N, Hepbasli A. Performance analysis of drying of green olive in a tray dryer. Journal of Food Engineering. 2007;80(4):1188-93.

[35] Sturm B, Nunez Vega A-M, Hofacker WC. Influence of process control strategies on drying kinetics, colour and shrinkage of air dried apples. Applied Thermal Engineering. 2014;62(2):455-60.

[36] Heldman D, Moraru C. Drying theory. Encyclopedia of Agricultural, Food, and Biological Engineering. 2003;1:1208.

[37] Kudra T. Energy performance of convective dryers. Drying Technology. 2012;30(11-12):1190-8.

[38] Altobelli F, Condorí M, Duran G, Martinez C. Solar dryer efficiency considering the total drying potential. Application of this potential as a resource indicator in north-western Argentina. Solar Energy. 2014;105:742-59.

[39] Adelaja AO, Babatope BI. Analysis and testing of a natural convection solar dryer for the tropics. Journal of Energy. 2013;2013:8. 
[40] Cacua K, Olmos-Villalba L, Herrera B, Gallego A. Experimental evaluation of a diesel-biogas dual fuel engine operated on micro-trigeneration system for power, drying and cooling. Applied Thermal Engineering. 2016;100:762-7.

[41] Okoroigwe EC, Ndu EC, Okoroigwe FC. Comparative evaluation of the performance of an improved solar-biomass hybrid dryer. Journal of Energy in Southern Africa. 2015;26:38-51.

[42] Helvac1 HU, Akkurt GG. Thermodynamic performance evaluation of a geothermal drying system.

In: Dincer I, Midilli A, Kucuk H, editors. Progress in exergy, energy, and the environment. Cham: Springer International Publishing; 2014. p. 331-41.

[43] Sumotarto U. Design of a geothermal energy drier for beans and grains drying in Kamojang Geothermal Field, Indonesia. GHC Bulletin. 2007;28:13-8.

[44] Mezrhab A, Elfarh L, Naji H, Lemonnier D. Computation of surface radiation and natural convection in a heated horticultural greenhouse. Applied Energy. 2010;87(3):894-900.

[45] Kumar R, Rosen MA. A critical review of photovoltaic-thermal solar collectors for air heating. Applied Energy. 2011;88(11):3603-14.

[46] Jain D, Tewari P. Performance of indirect through pass natural convective solar crop dryer with phase change thermal energy storage. Renewable Energy. 2015;80:244-50.

[47] Pirasteh G, Saidur R, Rahman SMA, Rahim NA. A review on development of solar drying applications. Renewable and Sustainable Energy Reviews. 2014;31:133-48.

[48] López-Vidaña EC, Méndez-Lagunas LL, Rodríguez-Ramírez J. Efficiency of a hybrid solar-gas dryer. Solar Energy. 2013;93:23-31.

[49] Misha S, Mat S, Ruslan MH, Salleh E, Sopian K. Performance of a solar assisted solid desiccant dryer for kenaf core fiber drying under low solar radiation. Solar Energy. 2015;112:194-204. 
[50] Ceylan İ, Gürel AE, Ergün A, Tabak A. Performance analysis of a concentrated photovoltaic and thermal system. Solar Energy. 2016;129:217-23.

[51] Mokhtarian M, Tavakolipour H, Kalbasi Ashtari A. Effects of solar drying along with air recycling system on physicochemical and sensory properties of dehydrated pistachio nuts. LWT - Food Science and Technology. 2017;75:202-9.

[52] Yassen TA, Al-Kayiem HH. Experimental investigation and evaluation of hybrid solar/thermal dryer combined with supplementary recovery dryer. Solar Energy. 2016;134:284-93.

[53] Renewable Energy for Food. Economic analysis of an innovative 5-Tonne capacity solar biomass hybrid dryer in ghana. RE4Food Project. 2016.

[54] Borah A, Sethi LN, Sarkar S, Hazarika K. Drying kinetics of sliced turmeric (Curcuma longa L.) in a solar-biomass integrated drying system. Journal of Food Processing and Preservation. 2017;41(3):1-7. [55] Amer BMA, Hossain MA, Gottschalk K. Design and performance evaluation of a new hybrid solar dryer for banana. Energy Conversion and Management. 2010;51(4):813-20.

[56] Gudiño-Ayala D, Calderón-Topete Á. Pineapple drying using a new solar hybrid dryer. Energy Procedia. 2014;57:1642-50.

[57] Saravanan D, Wilson VH, Kumarasamy S. Design and thermal performance of the solar biomass hybrid dryer for cashew drying. Mechanical Engineering. 2014;12:277-88.

[58] Hossain M, Amer BM, Gottschalk K. Hybrid solar dryer for quality dried tomatoes. Drying Technology:An International Journal. 2008;26:1591-601.

[59] Reyes A, Mahn A, Huenulaf P, González T. Tomato dehydration in a hybrid-solar dryer. Journal of Chemical Engineering \& Process Technology. 2014;5:196.

[60] Okoroigwe EC, Eke MN, Ugwu HU. Design and evaluation of combined solar and biomass dryer 
for small and medium enterprises for developing countries. International Journal of Physical Sciences. $2013 ; 8: 1341-9$

[61] Okoroigwe EC, Okoroigwe FC. Comparative evaluation of the performance of an improved solarbiomass hybrid dryer. 2015;26(4):38-51.

[62] Jiang L, Wang L, Wang R, Gao P, Song F. Investigation on cascading cogeneration system of ORC (Organic Rankine Cycle) and $\mathrm{CaCl}_{2} / \mathrm{BaCl}_{2}$ two-stage adsorption freezer. Energy. 2014;71:377-87.

[63] Nasruddin Aziz WHPMS. Calculation of cogeneration technology system in waste heat recovery of diesel engine exhaust gases for grain dryers. International Journal of Engineering Research \& Technology. 2015;4(2):616-20.

[64] Samadi SH, Gbonbadian B, Najafi G. Application of combined heat and power for drying agricultural products (apple slices) to save energy. International Journal of Natural and Engineering Sciences. 2013;7(2):86-92.

[65] Abe T, Basunia M, Basunia MA, Abe T. Performance study of a small engine waste heated bin dryer in deep bed drying of paddy. Agricultural Engineering International: the CIGR Ejournal. 2008;10:80-5. [66] Akhter MS, Nabi MN, Afroz Z. Recovery of waste heat from engine exhaust for utilisation in a paddy dryer. 2007:29-31.

[67] Elisante E, Chove B, Muchunguzi C. Development of technology for small-scale drying of fish and its by-products. AIChE Annual Meeting, Conference Proceedings. Salt Lake City, US. 2010.

[68] Sivakumar R, Elayaperumal A, Saravanan R. Studies on combined cooling and drying of agro products using air cooled internal heat recovered vapour absorption system. Applied Thermal Engineering. 2016;97:100-8.

[69] Luo X, Wang Y, Zhao J, Chen Y, Mo S, Gong Y. Grey relational analysis of an integrated cascade 
utilization system of geothermal water. International Journal of Green Energy. 2015;13(1):14-27.

[70] Bennett AS, Bern CJ, Richard TL, Anex RP. Corn grain drying using corn stover combustion and CHP systems. Transactions of the ASABE. 2007;50(6):2161-70.

[71] Serpagli A, Nagori GP, Amoriggi P, Calvosa C. The use of cassava wastes to produce energy: outcomes of a feasibility study implemented in Nigeria. Nigeria. 2010:38-40.

[72] Li H, Chen Q, Zhang X, Finney KN, Sharifi VN, Swithenbank J. Evaluation of a biomass drying process using waste heat from process industries: A case study. Applied Thermal Engineering. 2012;35:71-80.

[73] Jiang L, Wang L, Wang R, Zhu F, Lu Y, Roskilly AP. Experimental investigation on an innovative resorption system for energy storage and upgrade. Energy Conversion and Management. 2017;138:651-

8.

[74] Jiang L, Roskilly AP, Wang RZ, Wang LW, Lu YJ. Analysis on innovative modular sorption and resorption thermal cell for cold and heat cogeneration. Applied Energy. 2017;204:767-79.

[75] Jiang L, Wang RZ, Wang LW, Roskilly AP. Investigation on an innovative resorption system for seasonal thermal energy storage. Energy Conversion and Management. 2017;149:129-39.

[76] Kant K, Shukla A, Sharma A, Kumar A, Jain A. Thermal energy storage based solar drying systems: A review. Innovative Food Science \& Emerging Technologies. 2016;34:86-99.

[77] Sharma A, Tyagi VV, Chen CR, Buddhi D. Review on thermal energy storage with phase change materials and applications. Renewable and Sustainable Energy Reviews. 2009;13(2):318-45.

[78] Devaux P, Farid MM. Benefits of PCM underfloor heating with PCM wallboards for space heating in winter. Applied Energy. 2017;191:593-602.

[79] Oró E, de Gracia A, Castell A, Farid MM, Cabeza LF. Review on phase change materials (PCMs) 
for cold thermal energy storage applications. Applied Energy. 2012;99:513-33.

[80] Pati JR, Hotta SK, Mahanta P. Effect of Waste Heat Recovery on Drying Characteristics of Sliced Ginger in a Natural Convection Dryer. Procedia Engineering. 2015;105:145-52.

[81] Reyes A, Mahn A, Vásquez F. Mushrooms dehydration in a hybrid-solar dryer, using a phase change material. Energy Conversion and Management. 2014;83:241-8.

[82] Shalaby SM, Bek MA. Experimental investigation of a novel indirect solar dryer implementing PCM as energy storage medium. Energy Conversion and Management. 2014;83:1-8.

[83] Berroug F, Lakhal EK, El Omari M, Faraji M, El Qarnia H. Thermal performance of a greenhouse with a phase change material north wall. Energy and Buildings. 2011;43(11):3027-35.

[84] Devahastin S, Pitaksuriyarat S. Use of latent heat storage to conserve energy during drying and its effect on drying kinetics of a food product. Applied Thermal Engineering. 2006;26(14):1705-13.

[85] Shringi V, Kothari S, Panwar NL. Experimental investigation of drying of garlic clove in solar dryer using phase change material as energy storage. Journal of Thermal Analysis and Calorimetry. 2014;118(1):533-9.

[86] Sain P, Songara V, Karir R, Balan N. Natural convection type solar dryer with latent heat storage. International Conference on Renewable Energy and Sustainable Energy (ICRESE). Coimbatore, India. 2013; p. 9-14.

[87] Shanmugam V, Natarajan E. Experimental study of regenerative desiccant integrated solar dryer with and without reflective mirror. Applied Thermal Engineering. 2007;27(8):1543-51.

[88] Dina SF, Ambarita H, Napitupulu FH, Kawai H. Study on effectiveness of continuous solar dryer integrated with desiccant thermal storage for drying cocoa beans. Case Studies in Thermal Engineering. 2015;5:32-40. 
[89] Pathare PB, Roskilly AP. Quality and energy evaluation in meat cooking. Food Engineering Reviews. 2016;8(4):435-47.

[90] Hussein JB, Usman MA, Filli KB. Effect of hybrid solar drying method on the functional and sensory properties of tomato. American Journal of Food Science and Technology. 2016;4(5):141-8.

[91] Borah A, Sethi LN, Sarkar S, Hazarika K. Effect of drying on texture and color characteristics of ginger and turmeric in a solar biomass integrated dryer. Journal of Food Process Engineering. 2017;40(1):1-6.

[92] Morad MM, El-Shazly MA, Wasfy KI, El-Maghawry HAM. Thermal analysis and performance evaluation of a solar tunnel greenhouse dryer for drying peppermint plants. Renewable Energy. 2017;101:992-1004.

[93] Arazu N, Ogbeibu A. Traditional methods of fish smoking and drying in reducing loss to spoilage in selected fishing communities of Anambra State, Nigeria. Tropical Freshwater Biology. 2009;18:25-30. [94] Adeyeye SAO, Oyewole OB. An overview of traditional fish smoking in Africa. Journal of Culinary Science \& Technology. 2016;14(3):198-215.

[95] Alhassan E, Boateng V, Ndaigo C. Smoked and frozen fish consumption and marketing channels in the Tamale Metropolis of Ghana. Ghana Journal of Development Studies. 2012;9:21-8.

[96] Taşeri L, Aktaş M, Şevik S, Gülcü M, Uysal Seçkin G, Aktekeli B. Determination of drying kinetics and quality parameters of grape pomace dried with a heat pump dryer. Food Chemistry. 2018;260:152-

9.

[97] Lisboa HM, Duarte ME, Cavalcanti-Mata ME. Modeling of food drying processes in industrial spray dryers. Food and Bioproducts Processing. 2018;107:49-60.

[98] Onwude Daniel I, Hashim N, Janius Rimfiel B, Nawi Nazmi M, Abdan K. Modeling the thin-layer 
drying of fruits and vegetables: a review. Comprehensive Reviews in Food Science and Food Safety. 2016;15(3):599-618.

[99] Defraeye T. Advanced computational modelling for drying processes - A review. Applied Energy. 2014;131:323-44.

[100] Kemp IC. Drying software: past, present, and future. Drying Technology. 2007;25(7-8):1249-63 .

[101] Kemp IC, Hallas HJ, Oakley DE. Developments in aspen technology drying software. Proceedings of the 14th International Drying Symposium 2004:767-74.

[102] Gong Z-X, Mujumdar AS. Software for design and analysis of drying systems. Drying Technology. 2008;26(7):884-94.

[103] Yeboah IK. Application of MATLAB - based solar dryer for cocoa drying. Recent Researches in Applied Computers and Computational Science. 2012:252-8.

[104] Olawale AS, Omole SO. Thin layer drying models for sweet potato in tray dryer. Agricultural Engineering International: the CIGR Ejournal. 2012:131-7.

[105] Xu C, Xu G, Yang Y, Zhao S, Zhang K, Zhang D. An improved configuration of low-temperature pre-drying using waste heat integrated in an air-cooled lignite fired power plant. Applied Thermal Engineering. 2015;90:312-21.

[106] Gong Z-X, Mujumdar AS. Process simulation of combustion drying with simprosys software. Drying Technology. 2014;32(4):447-54.

[107] Jamaleddine TJ, Ray MB. Application of computational fluid dynamics for simulation of drying processes: a Review. Drying Technology. 2010;28(2):120-54.

[108] Punlek C, Pairintra R, Chindaraksa S, Maneewan S. Simulation design and evaluation of hybrid PV/T assisted desiccant integrated HA-IR drying system (HPIRD). Food and Bioproducts Processing. 
2009;87(2):77-86.

[109] Lokeswaran S, Eswaramoorthy M. An Experimental analysis of a solar greenhouse drier: computational fluid dynamics (CFD) validation. Energy Sources, Part A: Recovery, Utilization, and Environmental Effects. 2013;35(21):2062-71.

[110] Amjad W, Munir A, Esper A, Hensel O. Spatial homogeneity of drying in a batch type food dryer with diagonal air flow design. Journal of Food Engineering. 2015;144:148-55.

[111] Misha S, Mat S, Ruslan MH, Sopian K, Salleh E. The CFD simulation of tray dryer design for kenaf core drying. Applied Mechanics and Materials. 2013;393:717-22.

[112] Abunde Neba F, Jiokap Nono Y. Modeling and simulated design: A novel model and software of a solar-biomass hybrid dryer. Computers \& Chemical Engineering. 2017;104:128-40.

[113] Curcio S, Aversa M, Calabrò V, Iorio G. Simulation of food drying: FEM analysis and experimental validation. Journal of Food Engineering. 2008;87(4):541-53.

[114] De Bonis MV, Ruocco G. A generalized conjugate model for forced convection drying based on an evaporative kinetics. Journal of Food Engineering. 2008;89(2):232-40.

[115] Marra F, De Bonis MV, Ruocco G. Combined microwaves and convection heating: A conjugate approach. Journal of Food Engineering. 2010;97(1):31-9.

[116] Keshavarz Moraveji M, Ghaderi E, Davarnejad R. Simulation of the transport phenomena during food drying with ohmic heating in a static system. International Journal of Food Engineering. 2010;6(5):1-8.

[117] Defraeye T, Herremans E, Verboven P, Nicolai B, Carmeliet J. Flow and scalar exchange for horticultural products using cfd: Performance of turbulence and boundary-layer modelling approaches. International Symposium on CFD Applications in Agriculture. Leuven, Belgium. 2013; p. 99-104. 
[118] Li S, Stawczyk J, Zbicinski I. CFD Model of apple atmospheric freeze drying at low temperature. Drying Technology. 2007;25(7-8):1331-9.

[119] Defraeye T, Herremans E, Verboven P, Carmeliet J, Nicolai B. Convective heat and mass exchange at surfaces of horticultural products: A microscale CFD modelling approach. Agricultural and Forest Meteorology. 2012;162-163:71-84.

[120] Piscia D, Montero JI, Baeza E, Bailey BJ. A CFD greenhouse night-time condensation model. Biosystems Engineering. 2012;111(2):141-54.

[121] Kaya A, Aydın O, Dincer I. Numerical modeling of heat and mass transfer during forced convection drying of rectangular moist objects. International Journal of Heat and Mass Transfer. 2006;49(17):3094103.

[122] Tsatsaronis G. Definitions and nomenclature in exergy analysis and exergoeconomics. Energy. 2007;32(4):249-53.

[123] Aghbashlo M, Mobli H, Rafiee S, Madadlou A. A review on exergy analysis of drying processes and systems. Renewable and Sustainable Energy Reviews. 2013;22:1-22.

[124] Dincer I, Rosen MA. Thermodynamic aspects of renewables and sustainable development. Renewable and Sustainable Energy Reviews. 2005;9(2):169-89.

[125] Amjad W, Hensel O, Munir A, Esper A, Sturm B. Thermodynamic analysis of drying process in a diagonal-batch dryer developed for batch uniformity using potato slices. Journal of Food Engineering. 2016;169:238-49.

[126] Dincer I, Sahin AZ. A new model for thermodynamic analysis of a drying process. International Journal of Heat and Mass Transfer. 2004;47(4):645-52.

[127] Vaughan GL, Carrington CG, Sun ZF. Exergy analysis of wood-stack during dehumidifier drying. 
International Journal of Exergy. 2007;4:151-67.

[128] Hancioglu E, Hepbasli A, Icier F, Erbay Z, Colak N. Performance investigation of the drying of parsley in a tray dryer. International Journal of Exergy. 2010;7(2):193-210.

[129] Luo X, Wang Y, Zhao J, Chen Y, Mo S, Gong Y. Grey relational analysis of an integrated cascade utilization system of geothermal water. International Journal of Green Energy. 2016;13(1):14-27.

[130] Hancioglu Kuzgunkaya E, Hepbasli A. Exergetic Performance Assessment of a ground source heat pump drying system. International Journal of Energy Research. 2007;31:760-70.

[131] Aziz M, Oda T, Kashiwagi T. Integration of energy-efficient drying in microalgae utilization based on enhanced process integration. Energy. 2014;70:307-16.

[132] Ganjehsarabia H, Dincer I, Gungora A. Exergoeconomic analysis of a heat pump tumbler dryer. Drying Technology: An International Journal. 2013;32(3):352-60.

[133] Daghigh R, Shafieian A. Energy-exergy analysis of a multipurpose evacuated tube heat pipe solar water heating-drying system. Experimental Thermal and Fluid Science. 2016;78:266-77.

[134] Soltani R, Dincer I, Rosen MA. Thermodynamic analysis of a novel multigeneration energy system based on heat recovery from a biomass CHP cycle. Applied Thermal Engineering. 2015;89:90-100.

[135] Coskun C, Bayraktar M, Oktay Z, Dincer I. Energy and exergy analyses of an industrial wood chips drying process. International Journal of Low-Carbon Technologies. 2009;4(4):224-9.

[136] Sarker MSH, Ibrahim MN, Abdul Aziz N, Punan MS. Energy and exergy analysis of industrial fluidized bed drying of paddy. Energy. 2015;84:131-8.

[137] Ghasemkhani H, Keyhani A, Aghbashlo M, Rafiee S, Mujumdar AS. Improving exergetic performance parameters of a rotating-tray air dryer via a simple heat exchanger. Applied Thermal Engineering. 2016;94:13-23. 
[138] Tiwari S, Tiwari GN, Al-Helal IM. Performance analysis of photovoltaic-thermal (PVT) mixed mode greenhouse solar dryer. Solar Energy. 2016;133:421-8.

[139] Boulemtafes-Boukadoum A, Benzaoui A. Energy and exergy analysis of solar drying process of Mint. Energy Procedia. 2011;6(5):583-91.

[140] Tiwari GN, Das T, Chen CR, Barnwal P. Energy and exergy analyses of greenhouse fish drying. International Journal of Exergy. 2009;6(5):620-36.

[141] Celma AR, Cuadros F. Energy and exergy analyses of OMW solar drying process. Renewable Energy. 2009;34(3):660-6.

[142] Akbulut A, Durmuş A. Energy and exergy analyses of thin layer drying of mulberry in a forced solar dryer. Energy. 2010;35(4):1754-63.

[143] Chowdhury MMI, Bala BK, Haque MA. Energy and exergy analysis of the solar drying of jackfruit leather. Biosystems Engineering. 2011;110(2):222-9.

[144] Yahya M, Fudholi A, Sopian K. Energy and exergy analyses of solar-assisted fluidized bed drying integrated with biomass furnace. Renewable Energy. 2017;105:22-9.

[145] Rabha DK, Muthukumar P, Somayaji C. Energy and exergy analyses of the solar drying processes of ghost chilli pepper and ginger. Renewable Energy. 2017;105:764-73.

[146] Aktaş M, Khanlari A, Amini A, Şevik S. Performance analysis of heat pump and infrared-heat pump drying of grated carrot using energy-exergy methodology. Energy Conversion and Management. 2017;132:327-38.

[147] Beigi M, Tohidi M, Torki-Harchegani M. Exergetic analysis of deep-bed drying of rough rice in a convective dryer. Energy. 2017;140:374-82.

[148] Fudholi A, Sopian K, Gabbasa M, Bakhtyar B, Yahya M, Ruslan MH, Mat S. Techno-economic of 
solar drying systems with water based solar collectors in Malaysia: A review. Renewable and Sustainable Energy Reviews. 2015;51:809-20.

[149] Boroze T, Desmorieux H, Méot J-M, Marouzé C, Azouma Y, Napo K. Inventory and comparative characteristics of dryers used in the sub-Saharan zone: Criteria influencing dryer choice. Renewable and Sustainable Energy Reviews. 2014;40:1240-59.

[150] Toillier A, de Lapeyre de Bellaire L. Contribution of research to innovation within agri-chains. Sustainable Development and Tropical Agri-chains. 2017; 93-105.

[151] Nonclercq A, Spreutels L, Boey C, Lonys L, Dave B, Haut B. Construction of a solar drying unit suitable for conservation of food and enhancement of food security in West Africa. Food Security. 2009;1(2):197-205.

[152] Hamdani, Rizal TA, Muhammad Z. Fabrication and testing of hybrid solar-biomass dryer for drying fish. Case Studies in Thermal Engineering. 2018;12:489-96.

[153] Dhanushkodi S,Wilson VH, Sudhakar K. Life cycle cost of solar biomass hybrid dryer. Systems for Cashew Drying of Nuts in India. 2015;15(1):22.

[154] Singh M, Sethi VP. On the design, modelling and analysis of multi-shelf inclined solar cookercum-dryer. Solar Energy. 2018;162:620-36.

[155] Elkhadraoui A, Kooli S, Hamdi I, Farhat A. Experimental investigation and economic evaluation of a new mixed-mode solar greenhouse dryer for drying of red pepper and grape. Renewable Energy. $2015 ; 77: 1-8$

[156] Fudholi A, Othman MY, Ruslan MH, Yahya K, Zaharim A, Sopian K. Techno-economic analysis of solar drying system for seaweed in Malaysia. 7th IASME/WSEAS International conference Malaysia. 2011; p. 89-95. 
[157] Nayak S, Naaz Z, Yadav P, Chaudhary R. Economic analysis of hybrid photovoltaic-thermal ( PVT ) integrated solar dryer. International Journal of Engineering Intervention. 2012;1(11):21-7.

[158] Singh Chauhan P, Kumar A, Nuntadusit C, Mishra SS. Drying kinetics, quality assessment, and economic analysis of bitter gourd flakes drying inside forced convection greenhouse dryer. Journal of Solar Energy Engineering. 2018;140(5):051001-10.

[159] Nabnean S, Janjai S, Thepa S, Sudaprasert K, Songprakorp R, Bala BK. Experimental performance of a new design of solar dryer for drying osmotically dehydrated cherry tomatoes. Renewable Energy. 2016;94:147-56.

[160] Rupf GV, Bahri PA, de Boer K, McHenry MP. Barriers and opportunities of biogas dissemination in Sub-Saharan Africa and lessons learned from Rwanda, Tanzania, China, India, and Nepal. Renewable and Sustainable Energy Reviews. 2015;52:468-76.

[161] Barnhart SL. Teaching sustainability across scale and culture: biogas in context. Journal of Sustainable Eduaction. 2012;3:15.

[162] Mittal S, Ahlgren EO, Shukla PR. Barriers to biogas dissemination in India: A review. Energy Policy. 2018;112:361-70.

[163] Uusitalo A, Uusitalo V, Grönman A, Luoranen M, Jaatinen-Värri A. Greenhouse gas reduction potential by producing electricity from biogas engine waste heat using organic Rankine cycle. Journal of Cleaner Production. 2016;127:399-405.

[164] Hall CW. Handbook of industrial drying. Drying Technology. 1988;6(3):571-3.

[165] Bowser TJ, Frazier RS, Kakarala RR. Improvement of efficiency and environmental impact of a low-cost food dehydrator. The Open Food Science Journal. 2011;5:37-41.

[166] Prakash O, Kumar A. Environomical analysis and mathematical modelling for tomato flakes drying 
in a modified greenhouse dryer under active mode. International Journal of Food Engineering. 2014;10;

$669-681$ 